Article

\title{
The Role of Calcium and Strontium as the Most Dominant Elements during Combinations of Different Alkaline Earth Metals in the Synthesis of Crystalline Silica-Carbonate Biomorphs
}

\author{
Mayra Cuéllar-Cruz ${ }^{1,2, *(D)}$ and Abel Moreno ${ }^{2, *(D)}$ \\ 1 Departamento de Biología, División de Ciencias Naturales y Exactas, Campus Guanajuato, \\ Universidad de Guanajuato, Noria Alta S/N, Col. Noria Alta, Guanajuato C.P. 36050, Mexico \\ 2 Instituto de Química, Universidad Nacional Autónoma de México, Av. Universidad 3000, \\ Ciudad Universitaria, Ciudad de México 04510, Mexico \\ * Correspondence: mcuellar@ugto.mx (M.C.-C.); carcamo@unam.mx (A.M.)
}

Received: 22 June 2019; Accepted: 22 July 2019; Published: 24 July 2019

\begin{abstract}
The origin of life from the chemical point of view is an intriguing and fascinating topic, and is of continuous interest. Currently, the chemical elements that are part of the different cellular types from microorganisms to higher organisms have been described. However, although science has advanced in this context, it has not been elucidated yet which were the first chemical elements that gave origin to the first primitive cells, nor how evolution eliminated or incorporated other chemical elements to give origin to other types of cells through evolution. Calcium, barium, and strontium silica-carbonates have been obtained in vitro and named biomorphs, because they mimic living organism structures. Therefore, it is considered that these forms can resemble the first structures that were part of primitive organisms. Hence, the objective of this work was to synthesize biomorphs starting with different mixtures of alkaline earth metals-beryllium $\left(\mathrm{Be}^{2+}\right)$, magnesium $\left(\mathrm{Mg}^{2+}\right)$, calcium $\left(\mathrm{Ca}^{2+}\right)$, barium $\left(\mathrm{Ba}^{2+}\right)$, and strontium $\left(\mathrm{Sr}^{2+}\right)$-in the presence of nucleic acids, RNA and genomic DNA (gDNA). Our results allow us to infer that the stability of calcium followed by strontium had played an important role in the evolution of life since the Precambrian era until our current age. In this way, the presence of these two chemical elements as well as silica (in the primitive life) and some organic molecules give origin to a great variety of life forms, in which calcium is the most common dominating element in many living organisms as we know nowadays.
\end{abstract}

Keywords: chemical origin of life; biomorphs; $\mathrm{CaCO}_{3}$ polymorphs; $\mathrm{SrCO}_{3}$ polymorphs

\section{Introduction}

Since ancient times, humans have been trying to define life, without yet reaching a universally accepted definition. However, there are diverse hypotheses and theories from several branches of science that emphasize the unique abilities, characteristics, and properties that distinguish living organisms from inanimate matter. Understanding how life originated and how it has been conserved for millions of years is an intriguing and interesting topic and of permanent discussion. The first hypothesis on life's origin was conceived from a chemical point of view [1]. Oparin proposed that in the presence of a reducing atmosphere in the primitive Earth, the action of high temperatures and ultraviolet radiation, from the gradual chemical evolution of molecules based on carbon and contained in a primordial soup, favored the formation of more complex organic substances that gave origin to the first molecules, which eventually gave rise to life [1]. The order of the synthesis of biomolecules that allowed for the appearance of primitive cells from which life emerged resulted in a difficult to 
explain topic. Hence, in 1981, some researchers determined that the sequences of the ribosomal RNA of some protozoa, like Tetrahymena, have the ability to behave as enzymes, as they catalyze specific ruptures of sequences and allow linking reactions in substrates of RNA molecules [2,3]. Based on these results, it was determined that RNA was the first biomolecule that emerged in the primitive era. This knowledge has enabled us to understand cellular mechanisms for cell maintenance. Additionally, contemporary biology, specifically biochemistry, has allowed us to know the chemical elements that constitute living organisms. The elements that currently constitute mostly life are hydrogen $(\mathrm{H})$, carbon $(\mathrm{O})$, nitrogen $(\mathrm{N})$, oxygen $(\mathrm{O})$, and sulfur $(\mathrm{S})$. In addition, organisms need other essential elements at a lower proportion, like sodium $(\mathrm{Na})$, potassium $(\mathrm{K})$, magnesium $(\mathrm{Mg})$, calcium $(\mathrm{Ca})$, iron $(\mathrm{Fe})$, and/or manganese (Mn), cobalt (Co), zinc ( $\mathrm{Zn})$, molybdenum (Mo), selenium (Se), and chlorine (Cl) [4-6]. Interestingly, there are other life forms in which the required essential chemical elements are different, thus, they have incorporated some additional elements, like strontium (Sr), barium (Ba), boron $(\mathrm{B})$, silicon $(\mathrm{Si})$, arsenic $(\mathrm{As})$, bromine $(\mathrm{Br})$, iodine $(\mathrm{I})$, vanadium $(\mathrm{V})$, chromium $(\mathrm{Cr})$, nickel $(\mathrm{Ni})$, copper $(\mathrm{Cu})$, cadmium $(\mathrm{Cd})$, and wolfram $(\mathrm{W})$ [5-7]. These data indicate that the different chemical elements' requirements for each species must be the result of evolution in response to its adaptation to different habitats.

Currently it is known that the survival of a microorganism, a cell line, and an organism depends on its metabolome, which is defined as the set of biomolecules (RNA, DNA, proteins, carbohydrates, and lipids) with their elementary content [5]. Notwithstanding, although science has advanced in this route, the first elements that gave origin to the first primitive cell have not been described nor how evolution eliminated or incorporated other chemical elements to give origin to other types of cells along evolution. Identifying the first chemical elements that were part of the primitive cells structure is not an easy task, however, remnants of the first forms of life have been found in sedentary plates, which date back to the Precambrian era [8]. To be able to elucidate the elemental chemical composition of the first cells that existed in the Precambrian era is fundamental because it would help to understand evolution along the different eras. In this sense aiming at understanding which were the first structures formed in the Precambrian era with certain chemical elements in the presence of the first biomolecules reported to have existed in that era (RNA and DNA) [9], we decided to start with some chemical elements in the presence of RNA and DNA to assess the influence of nucleic acids in the formation of specific compounds. These compounds are the so-called silica-carbonates, because, in the last decades, silica-carbonates of calcium, barium, and strontium have been obtained in vitro; these have been called biomorphs because they mimic structures of living organisms. Therefore, it is considered that their form can resemble the first structures that were part of primitive organisms [10-12], because the chemical properties of a compound are determined by the arrangement, number, and types of atoms that constitute the compound. The synthesis mechanism of biomorphs is relatively simple as they are formed from self-assembled silica-carbonate nanocrystals to give origin to highly ordered complex structures in micrometers or millimeter scales, which mimic architectures of organisms obtained through biomineralization processes [13]. The differences in the type of links of molecules are of special relevance in living organisms. Even though, biomorphs have been obtained at different temperatures, reagent concentrations [14-16] and, recently, in the presence of nucleic acids (RNA, genomic DNA, and plasmid DNA) in a mixture of chemical elements, it has not been analyzed which is the chemical element that predominates over the others in the synthesis of biomorphs [14]. This determination would help to understand, partially, the reason why only some chemical elements have been conserved in living organisms along millions of years. With the aim of evaluating which is the predominating element in a metallic-type mixture containing several elements and a biomolecule, we synthesized biomorphs from different mixtures of alkaline earth metals-beryllium $\left(\mathrm{Be}^{2+}\right)$, magnesium $\left(\mathrm{Mg}^{2+}\right)$, calcium $\left(\mathrm{Ca}^{2+}\right)$, barium $\left(\mathrm{Ba}^{2+}\right)$, and strontium $\left(\mathrm{Sr}^{2+}\right)$-in the presence of nucleic acids, that is, RNA and genomic DNA (gDNA). The structure of the obtained biomorphs was identified through scanning electron microscopy (SEM). Chemical composition and the crystalline structure were determined through Raman microspectroscopy. Results showed that in both the obtained biomorphs and the solid 
structures formed, the most abundant element was calcium followed by strontium. These results allow us to infer that probably the stability of calcium followed by strontium has enabled the conservation and evolution of life since the Precambrian era until our current age. In this way, the presence of these two chemical elements as well as silica (in the primitive life) and some organic molecules give origin to a great variety of life forms, in which calcium is the most common dominating element in many living organisms as we know nowadays.

\section{Materials and Methods}

\subsection{Strains Used for Nucleic Acids Extraction}

Extraction of nucleic acids (genomic DNA and RNA) was performed from a liquid culture of Candida albicans (Department of Microbiology, ENCB-IPN, Mexico City, Mexico). The culture medium used was YPD (10 g/L yeast extract, $20 \mathrm{~g} / \mathrm{L}$ peptone, and $20 \mathrm{~g} / \mathrm{L}$ glucose).

The bacterial strain Escherichia coli JM109 was used to obtain plasmid DNA. The culture medium used was Luria-Bertani (LB: $5 \mathrm{~g} / \mathrm{L}$ yeast extract, $10 \mathrm{~g} / \mathrm{L}$ tryptone, and $5 \mathrm{~g} / \mathrm{L} \mathrm{NaCl}$ ).

\subsection{Extraction of Genomic DNA}

The protocol used to extract the genomic DNA was in general as follows; C. albicans cells were suspended in $600 \mu \mathrm{L}$ of a lysis buffer, containing $7 \mathrm{M}$ urea, $50 \mathrm{mM}$ Tris- $\mathrm{HCl}, \mathrm{pH} 8.0,1 \%$ $\mathrm{N}$-lauroylsarcosine, $20 \mathrm{mM}$ EDTA, and $0.35 \mathrm{M} \mathrm{NaCl}$. The mixture was left to rest for $30 \mathrm{~min}$ at room temperature. Then, $600 \mu \mathrm{L}$ of phenol-chloroform-isoamyl alcohol was added at a proportion of 25:24:1, mixed and centrifuged at $12,000 \times g$ for $10 \mathrm{~min}$. Next, the aqueous phase was placed into a new assay tube, this last step was repeated until eliminating completely the organic phase. To precipitate the DNA, the clean aqueous phase was supplemented with an equal volume of isopropanol; the mixture was homogenized by inversion until observing the appearance of white strands. The homogeneous mixture was centrifuged at $14,000 \times g$ for $10 \mathrm{~min}$, the supernatant was discarded, and the pellet was resuspended in $500 \mu \mathrm{L}$ of $70 \%$ ethanol, homogenized in a vortex, and centrifuged at $12,000 \times g$ for 10 min. The supernatant was discarded, and the pellet was resuspended in sterile nuclease-free water, which contained $1 \mu \mathrm{L}$ RNAsa $(20 \mathrm{mg} / \mathrm{mL})$ and incubated at $37^{\circ} \mathrm{C}$ for $20 \mathrm{~min}$ to eliminate the RNA; the obtained gDNA was used in the synthesis of the biomorphs.

\subsection{RNA Extraction}

RNA was obtained with the Trizol technique. Briefly, the C. albicans cell pellet was washed five times with $1 \%$ diethyl pyrocarbonate (DEPC, Sigma-Aldrich, St. Louis, MO, USA). Then, cell rupture was achieved mechanically with the aid of a vortex and glass pearls. After cell lysis, Trizol and $200 \mu \mathrm{L}$ of chloroform were added to the sample to allow for the completed dissociation of the nucleic-protein complex, the sample was incubated for 2-3 $\mathrm{min}$ at room temperature. The mixture was centrifuged at $12,000 \times g$ for $15 \mathrm{~min}$ at $4{ }^{\circ} \mathrm{C}$, and the aqueous phase (which contains the RNA) was recovered and transferred to a new assay tube. The recovered aqueous phase was supplemented with $500 \mu \mathrm{L}$ of cold isopropyl alcohol, shaken gently, and incubated for $10 \mathrm{~min}$ at room temperature. Then, the sample was centrifuged at $12,000 \times g$ for $10 \mathrm{~min}$ at $4{ }^{\circ} \mathrm{C}$, the isopropanol was removed, adding immediately $1 \mathrm{~mL}$ of cold $75 \%$ ethanol, molecular biology grade, and centrifuging at $7500 \times \mathrm{g}$ for $5 \mathrm{~min}$ at $4{ }^{\circ} \mathrm{C}$. The ethanol was discarded, and the pellet was resuspended in DEPC water. To eliminate the DNA, the RNA samples were treated with DNAse (Invitrogen). The concentration of total RNA was determined through Nano Drop 2000/2000c (Thermo Scientific) at $260 \mathrm{~nm}$. The obtained RNA was used to form the biomorphs.

\subsection{Biomorphs Formation}

Biomorphs were synthesized in different mixture of chemical alkaline earth elements: beryllium (Be), magnesium $(\mathrm{Mg})$, calcium $(\mathrm{Ca})$, barium $(\mathrm{Ba})$, and strontium $(\mathrm{Sr})$. In all the different combinations 
of mixtures, a 1:1 relation was maintained of each of the elements. Procurement of biomorphs was achieved through the gas diffusion method [17]. Synthesis was performed on glass squares of $1 \mathrm{~mm}$ thickness; the size of the glass square was of $5 \mathrm{~mm} \times 5 \mathrm{~mm}$ height and width. The glass square was placed in a crystallization chamber, supplemented with $1000 \mathrm{ppm}$ of sodium metasilicate, beryllium, magnesium, calcium, barium, or strontium chloride at a final concentration of $20 \mathrm{mM}, 0.1 \mathrm{ng}$ genomic DNA, plasmid DNA, or RNA, at pH 11.0, adjusted with sodium hydroxide (Figure 1). Table 1 summarizes the different assessed combinations. All reagents were from Sigma-Aldrich. Experiments were performed at $37^{\circ} \mathrm{C}$. Biomorphs formation was performed during $24 \mathrm{~h}$. Experiments were repeated in triplicate.

a) Synthesis

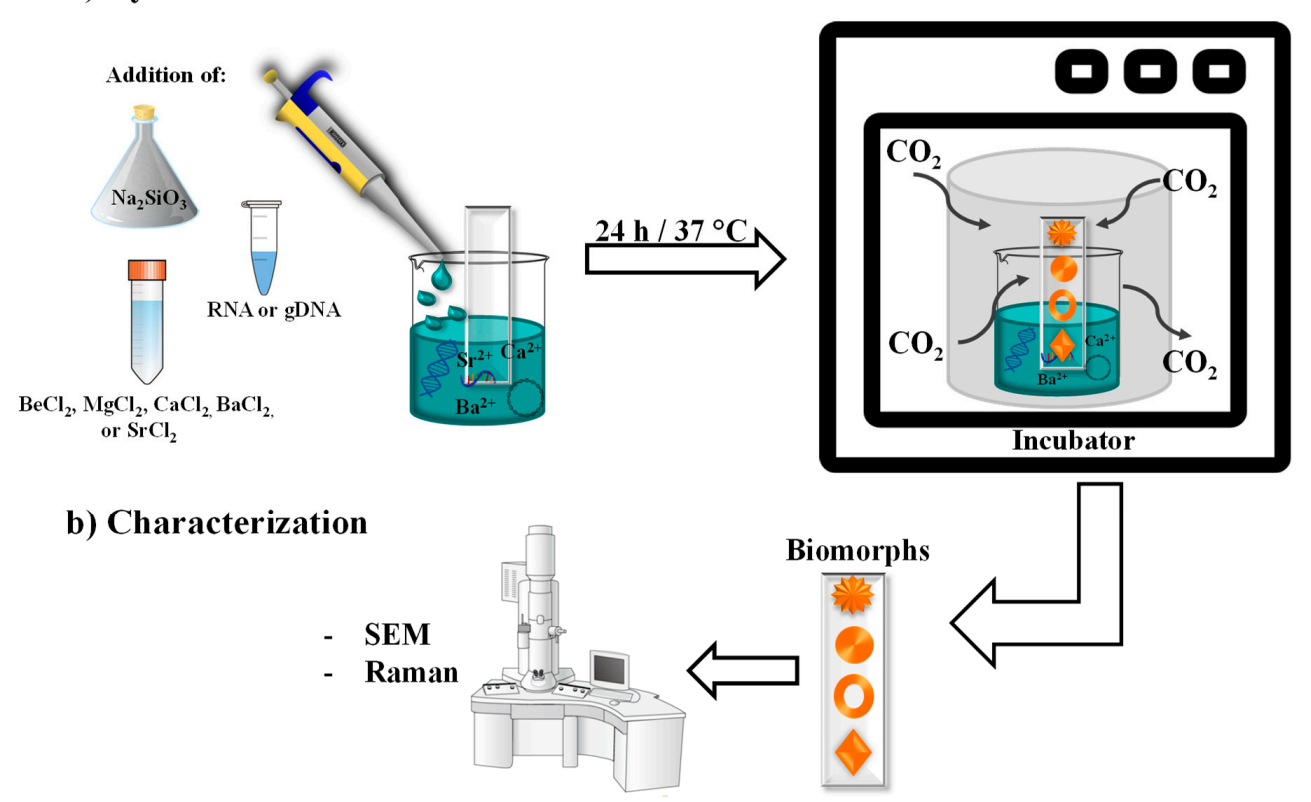

Figure 1. Synthesis and characterization of biomorphs.

Table 1. Combinations of different chemical elements in the presence of RNA and DNA.

\begin{tabular}{cl}
\hline Number of Combinations & Combinations \\
\hline 1 & $\mathrm{Ca}^{2+}+\mathrm{Mg}^{2+}$ \\
2 & $\mathrm{Ca}^{2+}+\mathrm{Mg}^{2+}+\mathrm{RNA}$ \\
3 & $\mathrm{Ca}^{2+}+\mathrm{Mg}^{2+}+\mathrm{gDNA}$ \\
4 & $\mathrm{Ba}^{2+}+\mathrm{Sr}^{2+}$ \\
5 & $\mathrm{Ba}^{2+}+\mathrm{Sr}^{2+}+\mathrm{RNA}$ \\
6 & $\mathrm{Ba}^{2+}+\mathrm{Sr}^{2+}+\mathrm{gDNA}$ \\
7 & $\mathrm{Ca}^{2+}+\mathrm{Ba}^{2+}+\mathrm{Sr}^{2+}$ \\
8 & $\mathrm{Ca}^{2+}+\mathrm{Ba}^{2+}+\mathrm{Sr}^{2+}+\mathrm{RNA}^{2+}$ \\
9 & $\mathrm{Ca}^{2+}+\mathrm{Ba}^{2+}+\mathrm{Sr}^{2+}+\mathrm{gDNA}^{2+} \mathrm{Be}^{2+}+\mathrm{Mg}^{2+}+\mathrm{Ca}^{2+}+\mathrm{Ba}^{2+}+\mathrm{Sr}^{2+}$ \\
10 & $\mathrm{Be}^{2+}+\mathrm{Mg}^{2+}+\mathrm{Ca}^{2+}+\mathrm{Ba}^{2+}+\mathrm{Sr}^{2+}+\mathrm{RNA}^{2+}$ \\
11 & $\mathrm{Be}^{2+}+\mathrm{Mg}^{2+}+\mathrm{Ca}^{2+}+\mathrm{Ba}^{2+}+\mathrm{Sr}^{2+}+\mathrm{gDNA}$ \\
\hline
\end{tabular}

\subsection{Characterization of Biomorphs}

Characterization of biomorphs was accomplished first by observing their morphology through SEM, using a model VEGA3 microscope (TESCAN, Brno, Czech Republic). Then, biomorphs were characterized through Raman spectroscopy (Figure 1). Raman measurements were performed with a confocal Raman microscope, WITec alpha300 R system, at room temperature. The Raman laser excitation wavelength was $532 \mathrm{~nm}$ and the spectral resolution of the spectrometer is $1.0 \mathrm{~cm}^{-1}$. Raman 
spectra were recorded with a WITec Alpha 300 Series Raman-AFM (WITec GmbH, Ulm, Germany) using a 672 lines/mm grating with 100x Zeiss objective (0.9 NA). A Nb:YVO $\mathrm{Yr}_{4}$ green laser with wavelength of $532 \mathrm{~nm}$ was used as an excitations source with $14.4 \mathrm{~mW}$ of laser power. Punctual Raman spectra had $0.5 \mathrm{~s}$ of integration time and 10 accumulations and map Raman with $0.03 \mathrm{~s}$ of integration time.

\section{Results and Discussion}

3.1. Composition of Biomorphs Depends on the Nature of the Chemical Elements, Whereas the Shape Depends on the Biomolecules

To contribute to understanding why some organisms have conserved certain chemical elements over others along the different geological eras, e.g., calcium is part of some bony structures, and in an attempt to elucidate how the first biomolecules (RNA and DNA), reported to have appeared in the Precambrian era in the presence of certain chemical elements, influenced the formation of certain structures as are the biomorphs, we evaluated the formation of these silica-carbonates biomorphs in different combinations. The first assessed cocktail combination was formed by $\mathrm{Ca}^{2+}$ and $\mathrm{Mg}^{2+}$ at a 1:1 proportion, in the presence or absence of RNA or gDNA. We chose these chemical elements because, aside from being alkaline earth metals, they are important constituents of current organisms. Calcium is the most abundant mineral in the human body, while magnesium is necessary for more than 300 biochemical reactions in the human body. As seen in Figure 2a, the biomorphs synthesized with calcium and magnesium presented a spherical morphology, but which also resembles a flower.

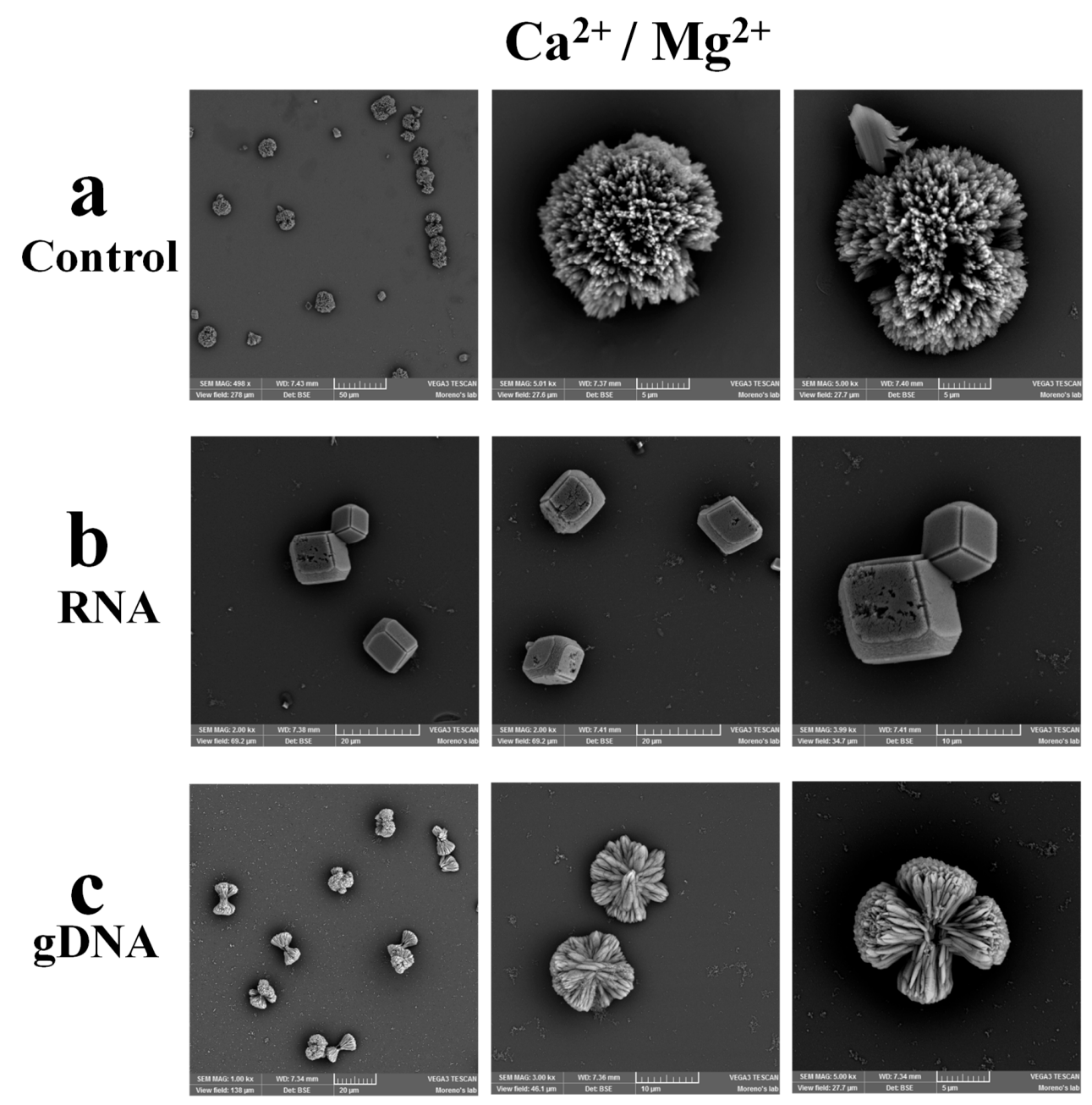

Figure 2. SEM microphotographs of the biomorphs obtained with the mixture of different ion compositions. (a) $\mathrm{Ca}^{2+} / \mathrm{Mg}^{2+}$, (b) $\mathrm{Ca}^{2+} / \mathrm{Mg}^{2+} / \mathrm{RNA}$, and (c) $\mathrm{Ca}^{2+} / \mathrm{Mg}^{2+} / \mathrm{gDNA}$. 
Biomorphs obtained in the presence of $\mathrm{Ca}^{2+}, \mathrm{Mg}^{2+}$, and RNA (Figure 2b) showed a rhombohedral morphology, in contrast to the morphology obtained without the nucleic acids (Figure 2a). This result is relevant because it indicates that biomolecules, such as RNA and gDNA, arrange the chemical elements to adopt a specific crystalline structure that is common when calcium is the sole chemical element forming the biomorph. This datum indicates that in the presence of the elements $\mathrm{Ca}^{2+}$ and $\mathrm{Mg}^{2+}$, the interaction of the nucleic acids with these elements favors calcium over magnesium, since the crystalline form found is common to $\mathrm{Ca}^{2+}$ (Figure 2b) with RNA, but different with gDNA (Figure 2c). These findings agree with previous results from our research team [14] and other groups that have shown that certain biomolecules, as are some peptides, modify the crystal habit of calcite [18]. Notwithstanding, although apparently both the gDNA and RNA direct the synthesis of the silica-carbonate biomorphs, it is necessary to know the chemical composition of the synthesized biomorphs, and to elucidate if a biomorph constituted by calcium and magnesium had been formed or rather one of these elements dominated the synthesis of the biomorph. To determine both the chemical composition and the crystalline phase of the obtained silica-carbonate biomorphs, Raman spectroscopy was used because it is a technique that enables to determine the polymorphs of crystalline compounds [19].

In the Raman spectrum for the biomorphs synthesized with $\mathrm{Ca}^{2+}$ and $\mathrm{Mg}^{2+}$, bands at 160,288 , 715 , and $1088 \mathrm{~cm}^{-1}$ were identified (Figure 3a). These peaks correspond to calcium carbonate $\left(\mathrm{CaCO}_{3}\right)$, specifically to the calcite polymorph with a trigonal structure, as reported by other authors $[20,21]$. In the analysis of biomorphs synthesized with the mixture of different ions/biomolecule made of $\mathrm{Ca}^{2+}$, $\mathrm{Mg}^{2+}$, and RNA (Figure 3b), spectra at different points of the biomorph were obtained to identify whether the chemical composition was the same or different in the whole structure of the biomorph. Punctual spectra presented vibrations at 160, 285, 715, and $1088 \mathrm{~cm}^{-1}$ (Figure $3 \mathrm{~b}$ ), which correspond to the calcite one polymorph of $\mathrm{CaCO}_{3}$. Whereas in the combination of $\mathrm{Ca}^{2+}, \mathrm{Mg}^{2+}$, and gDNA, the bands of the synthesized biomorphs were identified at 115, 117, 307, 1090, 1091, and $1092 \mathrm{~cm}^{-1}$ (Figure 3c). These vibrations correspond to the polymorph aragonite. These data are relevant because they show that calcium is the dominating element in the formation of the biomorphs over magnesium. Possibly, this event dominated in the organisms, and therefore their hard structures are formed by calcium and not magnesium. In this way, calcium in the form of $\mathrm{CaCO}_{3}$ is found as part of marine sponges, otoliths of all vertebrates, egg shells, seashells, bones, teeth, and nails [22-26]. Structures of organisms can present one or several of the three $\mathrm{CaCO}_{3}$ polymorphs (aragonite, calcite, and vaterite) $[27,28]$. For example, calcite and aragonite are the main phases found in marine organisms [29,30], whereas vaterite is found in few organisms [31,32]. The mechanisms by which some organisms synthesize preferentially one or another $\mathrm{CaCO}_{3}$ polymorph has not been elucidated yet; however, some authors refer that $\mathrm{CaCO}_{3}$ is initially precipitated as amorphous calcium carbonate to be later modified into stable polymorphs, as occurs in pearls that are formed by vaterite and aragonite [33,34]. It has also been reported that the formation of one or another polymorph depends on the environment; for example, it has been shown that vaterite can be generated in shells that are generally aragonitic but when found in fresh water change from aragonite to vaterite [35]. Our results agree with the above-cited information, because, even in the presence of magnesium, the prevalent polymorphs are calcite and aragonite (Figure 3). The prevalence of these polymorphs in the different structures of organisms is possibly because they have similar crystalline structures, in which the calcium ions are located in the same positions of the lattice layers (001), alternating with layers of carbonate ions [36]. In addition, the presence of $\mathrm{Mg}^{2+}$ favors the polymorph aragonite [36], as found in our mixture of different ions in the presence of gDNA (Figure 3c). As a whole, these data indicate that the composition of the organisms' structures are controlled by the nature of the chemical elements, whereas the shape of the structures are controlled by biomolecules, as are RNA and gDNA, as shown in previous works [14]. 

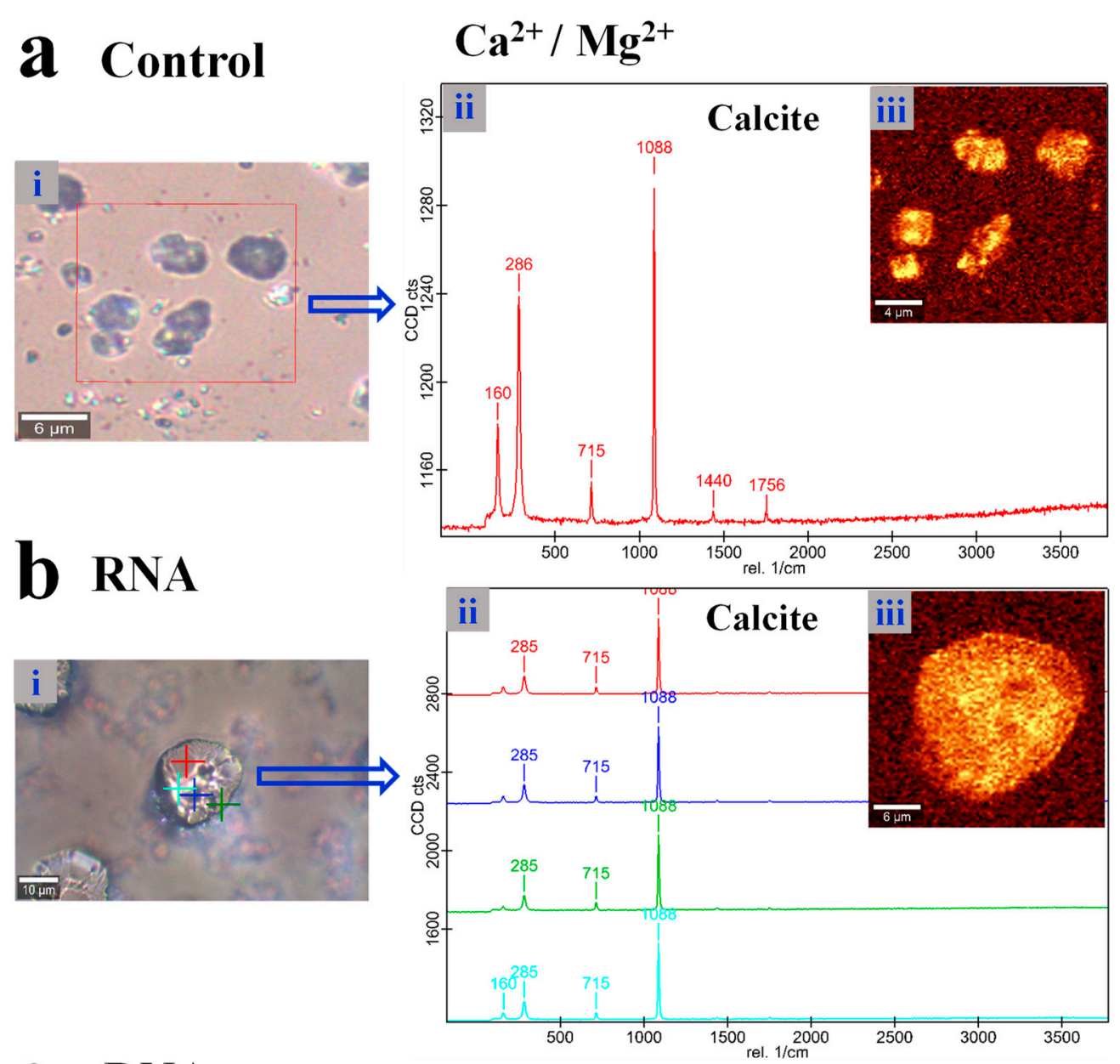

\section{C gDNA}
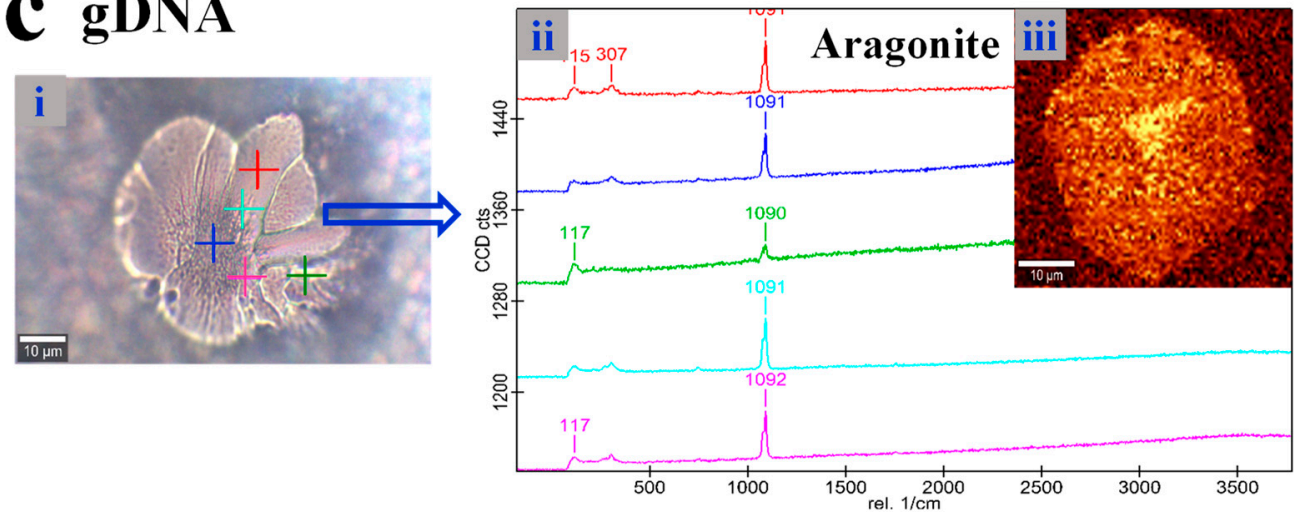

Figure 3. Raman punctual spectra of the biomorphs synthesized with the combinations: (a) $\mathrm{Ca}^{2+} / \mathrm{Mg}^{2+}$, (b) $\mathrm{Ca}^{2+} / \mathrm{Mg}^{2+} / \mathrm{RNA}$, and (c) $\mathrm{Ca}^{2+} / \mathrm{Mg}^{2+} / \mathrm{gDNA}$. (i) Optical image, (ii) multiple spectra, and (iii) mapping of biomorphs.

\subsection{Strontium is the Dominant Element in the Biomorphs Synthesized in a Combination of $\mathrm{Ba}^{2+}$ and $\mathrm{Sr}^{2+}$}

Other relevant elements to be analyzed are $\mathrm{Ba}^{2+}$ and $\mathrm{Sr}^{2+}$, because they have been conserved since ancient times until our current days. In this sense, strontium has been found in approximately 744 marine carbonates from the Phanerozoic era [37]. Currently, there are still organisms that contain strontium like algae, invertebrate organisms like Polyzoa, Crustacea, and Echinodermata; $\mathrm{Ba}^{2+}$ has also been found in algae, invertebrate species, and in fish of the Irish sea [38]. Based on the above information, we considered important to analyze, in a $\mathrm{Ba}^{2+}$ and $\mathrm{Sr}^{2+}$ mixture, which of the two is the predominant one in the formed biomorphs. For this, silica-carbonate biomorphs were obtained 
in the presence of a mixture of different ions made of $\mathrm{Ba}^{2+}$ and $\mathrm{Sr}^{2+}$ at a 1:1 proportion with or without RNA or gDNA. Biomorphs synthesized in the presence of only $\mathrm{Ba}^{2+}$ and $\mathrm{Sr}^{2+}$ were visualized through SEM. As seen in Figure 4a, biomorphs presented different morphologies that mimic flowers and bunches of flowers. The silica-carbonates obtained with the metallic combination of $\mathrm{Ba}^{2+}, \mathrm{Sr}^{2+}$, and RNA showed a morphology of circular and round structures linked through helix-type strands (Figure $4 \mathrm{~b}$ ). Interestingly, in these biomorphs a brilliant and an opaque part were observed, suggesting a possible different composition, as they were formed by a combination of two chemical elements and RNA. Some of the morphologies found in the obtained biomorphs have been previously described by other authors, such as cardioid structures (cardioid leaves), helicoidal forms (helicoidal filaments), funnel-like aggregates (circular and conic), worm form, braided structure, curly forms, framboidal forms, and fern-like forms [39]. The composition of the obtained structures was confirmed through Raman spectroscopy. In the biomorphs generated by the combination of $\mathrm{Ba}^{2+}, \mathrm{Sr}^{2+}$, and gDNA, morphologies similar to stems, leaves, and flowers were observed (Figure 4c).

\section{$\mathrm{Ba}^{2+} / \mathrm{Sr}^{2+}$}
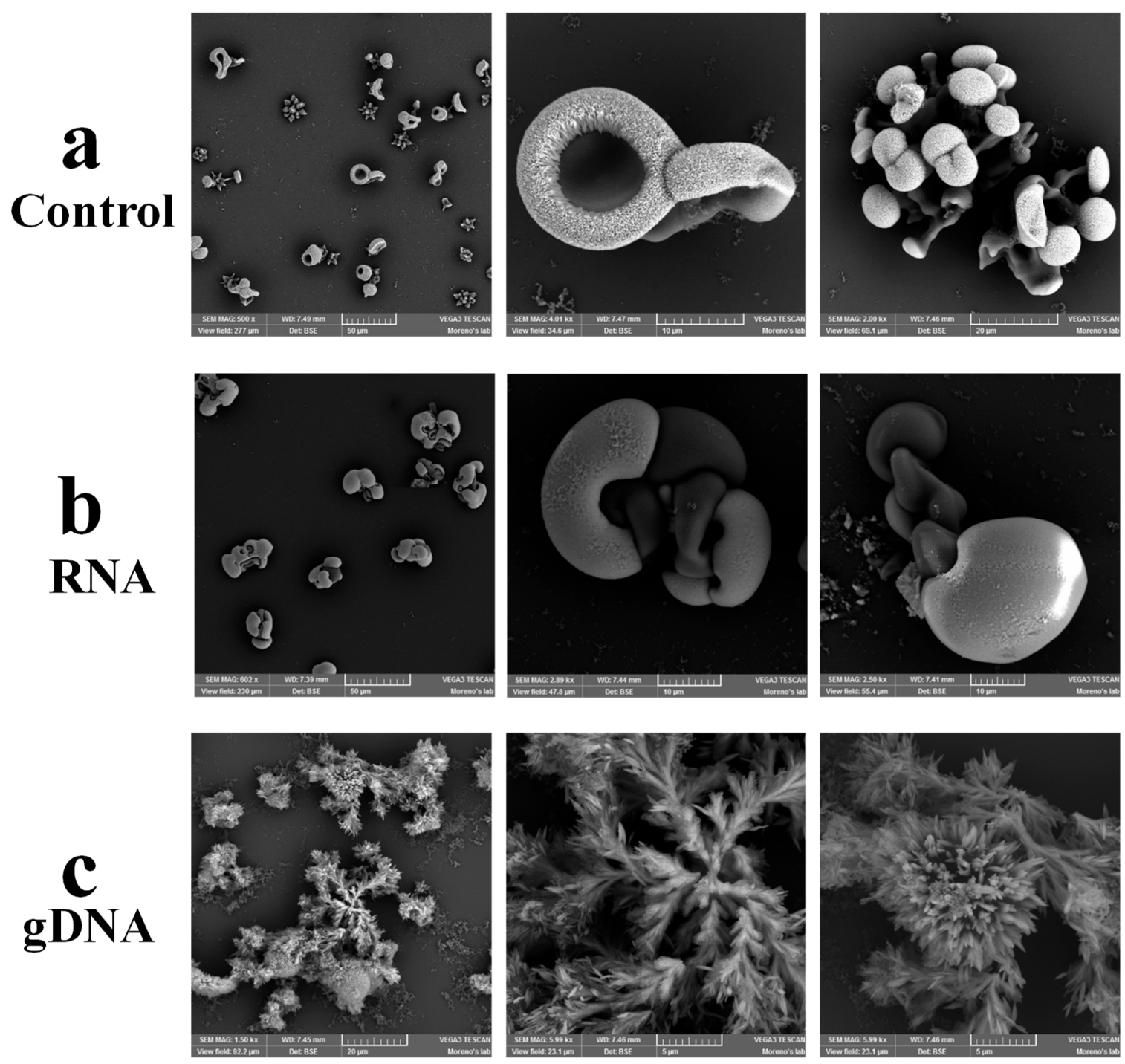

Figure 4. SEM microphotographs of the biomorphs obtained with the following mixtures of different ions/biomolecules: (a) $\mathrm{Ba}^{2+} / \mathrm{Sr}^{2+}$, (b) $\mathrm{Ba}^{2+} / \mathrm{Sr}^{2+} / \mathrm{RNA}$, and (c) $\mathrm{Ba}^{2+} / \mathrm{Sr}^{2+} / \mathrm{gDNA}$. 
Determination of the chemical composition as well as the crystalline phase of the silica-carbonate biomorphs generated with these chemical elements was performed through Raman spectroscopy. For this, multiple punctual spectra were obtained.

In five of the punctual spectra, corresponding to the sample with $\mathrm{Ba}^{2+}$ and $\mathrm{Sr}^{2+}$, vibrations at 144-147, 697, and $1068 \mathrm{~cm}^{-1}$ were identified (Figure 5a), which are characteristic of $\mathrm{SrCO}_{3}$ and correspond to the strontianite [40]. Also, in these biomorphs, one of the punctual spectra presented bands at 462, 902, and $1063 \mathrm{~cm}^{-1}$. These vibrations correspond to SrO [41]. Because the bands identified as of strontianite in the punctual spectra could be confused with $\mathrm{BaCO}_{3}$, we decided to perform a mapping of the complete biomorph and obtain a global spectrum, in which all bands could be distinguished and, thereby, confirm whether punctual spectra assignment had been correct. The spectrum corresponding to the mapping of the complete biomorph showed vibrations at 108, 146, 172, 242, 699, and $1067 \mathrm{~cm}^{-1}$ (Figure S1a in Supplementary Materials). These bands indeed correspond to strontianite because $\mathrm{BaCO}_{3}$ presents bands corresponding to the lattice vibration at $136,155,180$, and 225, as well as two bands of internal vibrations at 691 and $1059 \mathrm{~cm}^{-1}$ [42]. In the biomorphs synthesized in the combination of $\mathrm{Ba}^{2+}, \mathrm{Sr}^{2+}$, and RNA (Figure $5 \mathrm{~b}$ ), as well as with $\mathrm{Ba}^{2+}$, $\mathrm{Sr}^{2+}$, and gDNA (Figure 5c), bands at 110, 111, 142-147, 694-697, 1065-1068, and $1095 \mathrm{~cm}^{-1}$ were identified, these vibrations correspond to the strontianite $\left(\mathrm{SrCO}_{3}\right)$. In addition, as in the biomorphs obtained in the absence of RNA or DNA, a spectrum of complete biomorph mapping was also obtained from these biomorphs, to ensure their correct assignment. As shown in Figure S1b,c, spectra revealed the peaks corresponding to strontianite. This result is relevant and agrees with other previous works reporting that in several organisms like some algal species, invertebrates, and fishes, calcium and strontium have been identified, whereas barium has only been found in some cases [38]. These data indicate that although barium and strontium are similar chemical elements [43], strontium is the dominant element with respect to barium. Possibly, over time, this preference of strontium over barium gave these organisms an advantage over those organisms in which barium is part of their metabolism. The finding that the morphology is different for the three analyzed combinations (Figure 4), but their chemical composition is the same (Figure 5 and Figure S1), indicates that the arrangement of the crystalline networks of the obtained biomorphs depends on the nature of the elements, but the morphology depends on the nucleic acids, RNA and gDNA; the same was found for the $\mathrm{Ca}^{2+}$ and $\mathrm{Mg}^{2+}$ mixture (Figures 2 and 3). 

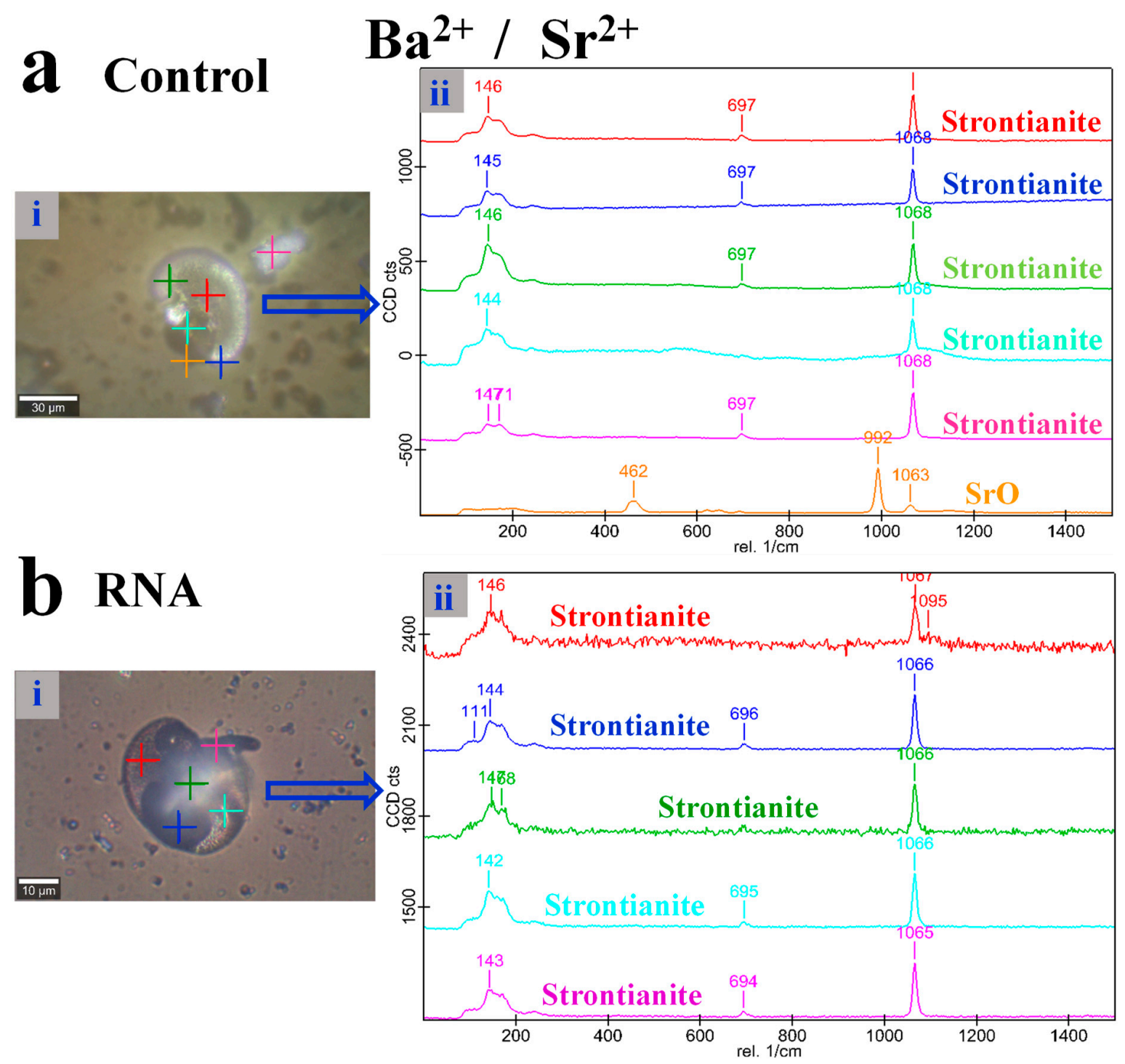

\section{C gDNA}
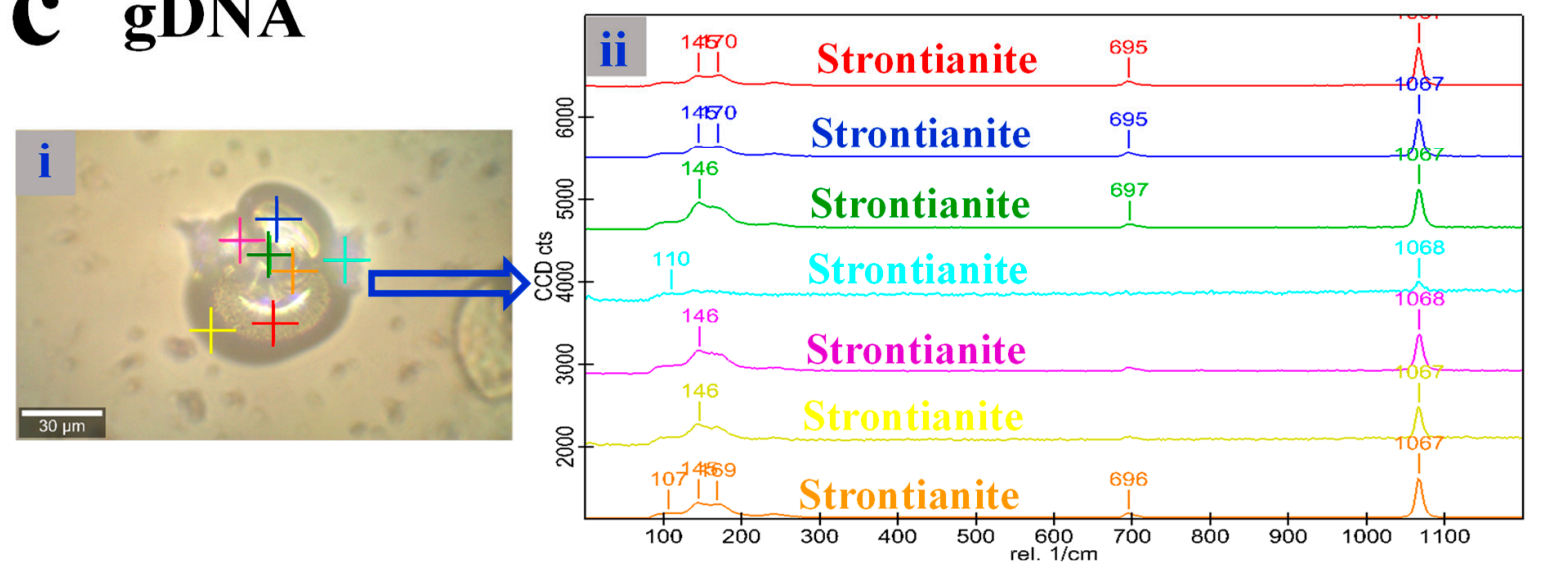

Figure 5. Raman punctual spectra of the biomorphs synthesized with the mixture of different ions/biomolecules: (a) $\mathrm{Ba}^{2+} / \mathrm{Sr}^{2+}$, (b) $\mathrm{Ba}^{2+} / \mathrm{Sr}^{2+} / \mathrm{RNA}$, and (c) $\mathrm{Ba}^{2+} / \mathrm{Sr}^{2+} / \mathrm{gDNA}$. (i) Optical image and (ii) multiple spectra. 


\subsection{In the Presence of Nucleic Acids, Calcium is the Element that Controls the Synthesis of Biomorphs}

Because barium and strontium present chemical similarity with calcium [44], we were interested in knowing which of these elements is the one to control the biomorphs synthesis in a mixture of different ions in which the three cations were present in the presence or absence of RNA and gDNA. In the silica-carbonate biomorphs obtained in the presence of only $\mathrm{Ca}^{2+}, \mathrm{Ba}^{2+}$, and $\mathrm{Sr}^{2+}, \mathrm{SEM}$ mainly revealed structures resembling stems and flowers and a minimal amount of rhombus-type morphologies (Figure 6a), whereas in the combinations of the three elements with RNA (Figure 6b) or gDNA (Figure 6c), the morphology was spherical. For these biomorphs, as done for the previous combinations, their chemical composition was also determined, as well as their crystalline structure through punctual spectra obtained with Raman spectroscopy; this type of spectra allow identifying the chemical composition in different points of the biomorph.
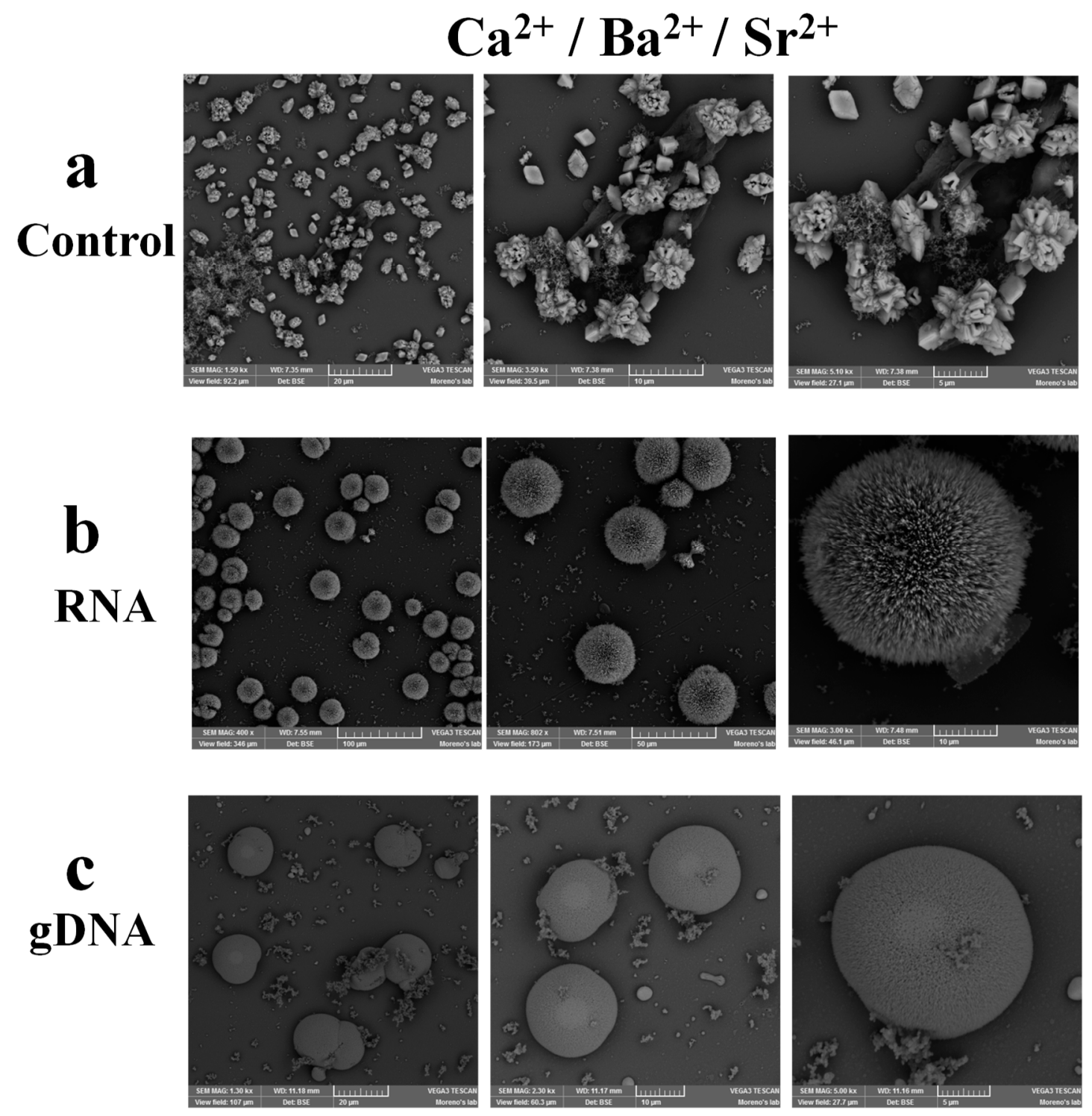

Figure 6. SEM microphotographs of biomorphs obtained with (b) $\mathrm{Ca}^{2+} / \mathrm{Ba}^{2+} / \mathrm{Sr}^{2+} / \mathrm{RNA}$, and (c) $\mathrm{Ca}^{2+} / \mathrm{Ba}^{2+} / \mathrm{Sr}^{2+} / \mathrm{gDNA}$.

(a) $\mathrm{Ca}^{2+} / \mathrm{Ba}^{2+} / \mathrm{Sr}^{2+}$,

The punctual spectra of the sample obtained with the three elements without nucleic acid showed vibrations at 156-158, 698, and 1071-1072 $\mathrm{cm}^{-1}$ (Figure 7a). However, determining the compound to 
which these vibrations corresponded was no easy task, as there was the possibility of dealing with a calcium, barium, or strontium compound, or a mixture of two or three elements.

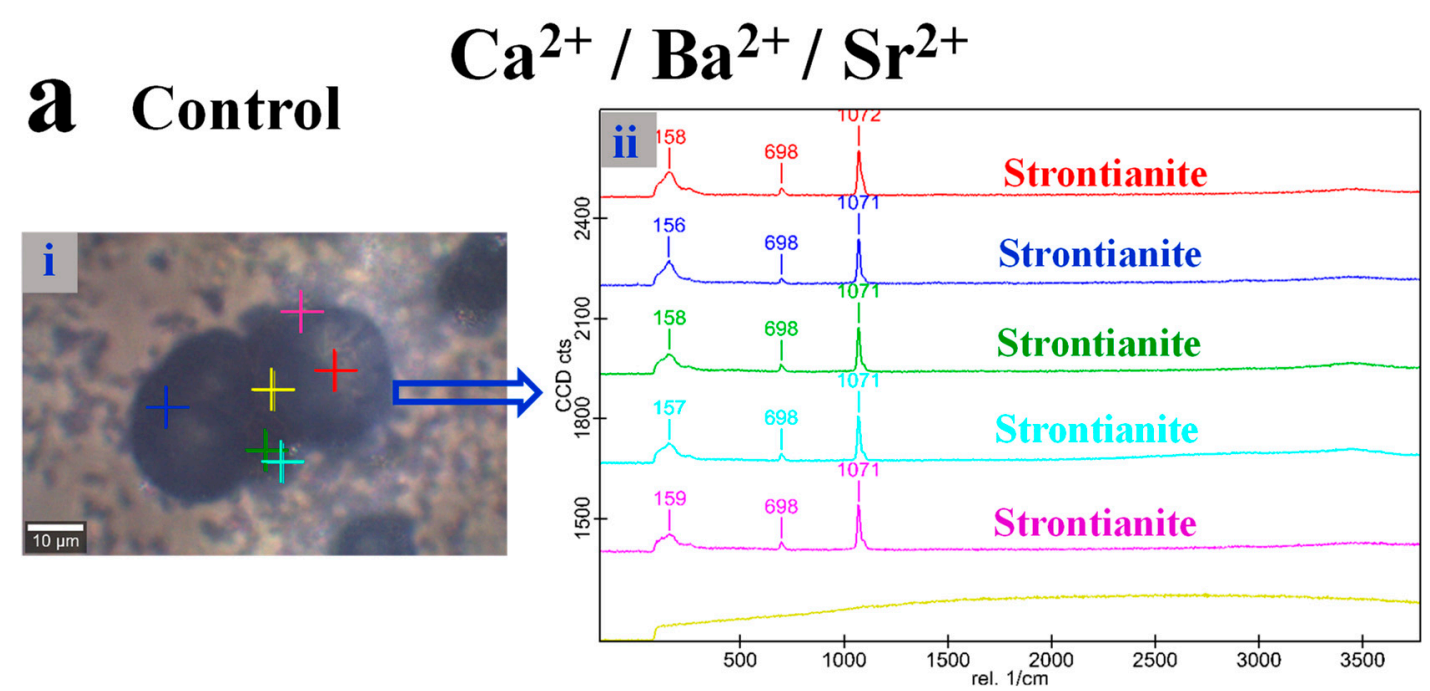

\section{b RNA}

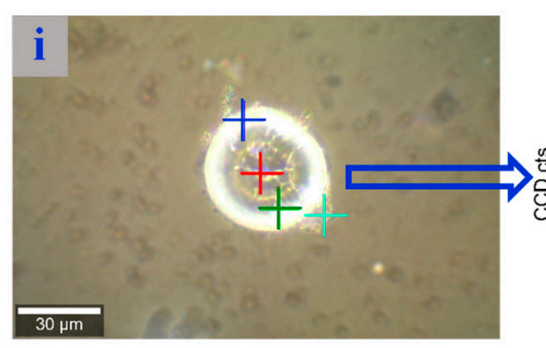

\section{C gDNA}
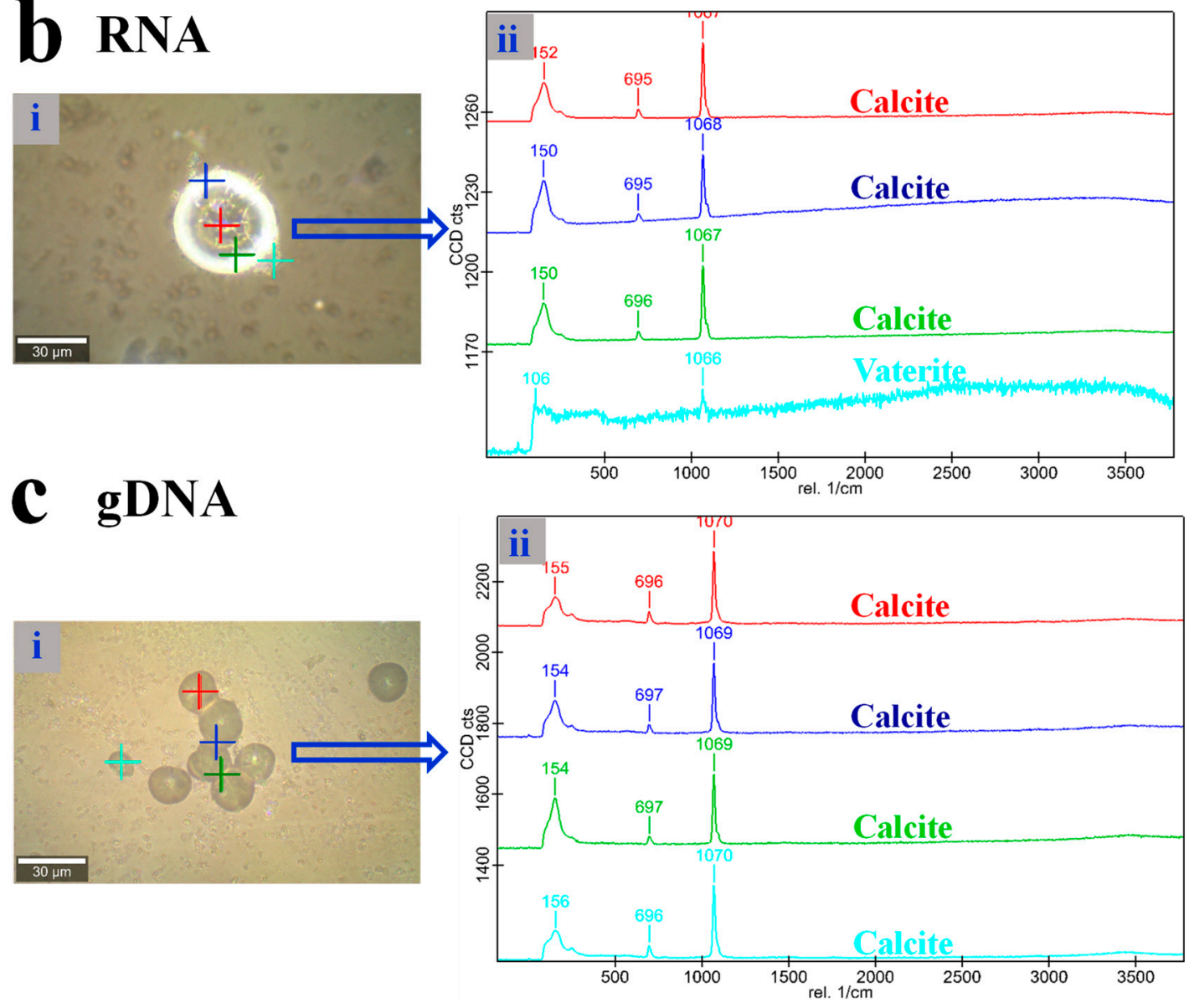

Figure 7. Raman multiple punctual spectra of biomorphs synthesized with (a) $\mathrm{Ca}^{2+} / \mathrm{Ba}^{2+} / \mathrm{Sr}^{2+}$, (b) $\mathrm{Ca}^{2+} / \mathrm{Ba}^{2+} / \mathrm{Sr}^{2+} / \mathrm{RNA}$, and (c) $\mathrm{Ca}^{2+} / \mathrm{Ba}^{2+} / \mathrm{Sr}^{2+} / \mathrm{gDNA}$. (i) Optical image and (ii) multiple spectra.

Faced with this complexity, we analyzed each vibration, and were able to determine that the formed compound was the strontianite $\left(\mathrm{SrCO}_{3}\right)$ (Figure $7 \mathrm{a}$ ), since none of the vibrations corresponded to a calcium or barium compound. Additionally, to confirm that the assignment had been correct, a global mapping was performed of the obtained biomorphs. The spectrum of the global mapping reveled peaks 
at $165,255,699$, and $1070 \mathrm{~cm}^{-1}$ (Figure S2a), which correspond to strontianite, confirming that, indeed, the biomorphs produced in the presence of $\mathrm{Ca}^{2+}, \mathrm{Ba}^{2+}$, and $\mathrm{Sr}^{2+}$ are composed of the strontianite. This result is important, because it indicates that strontium controls the synthesis of biomorphs in the presence of $\mathrm{Ca}^{2+}, \mathrm{Ba}^{2+}$, and $\mathrm{Sr}^{2+}$ (Figure 7a and Figure S2a). This is probably related with the fact that several of the primitive organisms that have been conserved since the Precambrian era until now, conserved strontium as an essential element participating in their metabolism, as this possibly granted them an advantage allowing them to survive over time [5-7]. These primitive organisms, probably, incorporated strontium in their metabolism as it was available in the Precambrian era and, along the years, conserved it because they keep obtaining it from their habitat. For example, it has been reported that strontium can be found in most soils [45], wetlands, and aquatic environments [44]. The biomorphs synthesized in the presence of $\mathrm{Ca}^{2+}, \mathrm{Ba}^{2+}, \mathrm{Sr}^{2+}$, and RNA (Figure 6b) or gDNA (Figure 6c) presented spherical morphology. When determining their chemical composition, the punctual spectra showed bands at $150-156,695-696$, and $1066-1070 \mathrm{~cm}^{-1}$ (Figure $7 \mathrm{~b}, \mathrm{c}$ ). These vibrations correspond to the polymorph calcite of $\mathrm{CaCO}_{3}$ for three punctual spectra of the biomorphs with RNA (Figure $7 \mathrm{~b}$ ), and for all punctual spectra of the sample with gDNA (Figure 6c). Additionally, in the case of biomorphs formed with RNA, one punctual spectrum corresponded to the polymorph vaterite of $\mathrm{CaCO}_{3}$ (Figure $7 \mathrm{~b}$ ). To confirm that the biomorphs synthesized in these mixtures corresponded mainly to calcite, global mappings of the biomorph were performed (Figure S2b,c). In the global mappings, peaks at 153-155, 697-696, and $1067-1070 \mathrm{~cm}^{-1}$ were identified, these vibrations indeed correspond to the polymorph calcite (Figure S2b,c). These results are very interesting, because in the presence of any of the nucleic acids (RNA or gDNA), calcium is the element that controls the synthesis of biomorphs over strontium and barium (Figure $7 b, c$ and Figure S2b,c), which does not occur in their absence (Figure 7a and Figure S2a). This information contributes to the knowledge that there were organisms in which calcium already participated in their metabolism in the presence of RNA (which has been postulated as the first biomolecule that appeared in the Precambrian era $[9,46]$ ); this is probably because nucleic acids select the element that provides the best thermodynamic stability and viability for the organisms, ensuring survival of species along millions of years [46]. In this sense, it has been reported that the polymorph calcite is thermodynamically more stable than aragonite and vaterite $[19,36]$. Notwithstanding, the identification of vaterite (Figure $7 \mathrm{~b}$ ) is an interesting result, because it has been reported that this polymorph can adopt multiple structures [28,47-49]. Therefore, being calcite the most stable polymorph, RNA and gDNA induce mainly the formation of this polymorph in the different structures of organisms, ensuring in this way the biological perpetuation of a species. As indicated previously, the calcite polymorph is part of echinoderms, sea urchins, ophiuroids, sea cucumbers, crinoids; arthropods like trilobites; mollusks like bivalves, gastropods, polyplacophorans, ammonoids, or nautiloids; calcareous seashells; and spicules of sponges, algae, eggshells, teeth, bones, and otoliths [23-25,50,51]. Calcium, besides forming part of the support structures of organisms, is also very important for cellular metabolism. For example, it plays a role as second messenger in eukaryote cells, as it produces the largest number of intracellular signals with physiological and pathological implications. In addition, calcium is involved in neurotransmission, muscle contraction, control of ion channels, gene expression, and cell death [52-54]. In plants, calcium is required in structures like the cell wall and membranes, it also activates and regulates cell division and cell enlargement and influences the specialization of cell organs [55]. Hence, calcium is essential for root, fruits, and leaf differentiation, and, in consequence, in the absence of calcium there will be no new leaves or flowers in a plant. In bacteria, calcium is needed at a relatively high concentration as it participates in maintaining the cellular structure, motility, cell differentiation processes; besides, it has been suggested that there is also calcium-dependent signals transduction like in eukaryote cells [56]. All together, these data demonstrate that in the presence of nucleic acids, in a combination where more than two chemical elements coexist, the chemical element with the best stability and viability for the cell will always be chosen; this element is clearly calcium, which can be considered an evolutionary achievement that developed from the first cells in the Precambrian era and has been conserved until 
our current times. Our data provide support to this fact, because life as we know it would not be possible without calcium.

3.4. Calcium and Strontium in the Presence of Nucleic Acids are Part of Solid Structures Obtained from a Mixture with Multiple Chemical Elements

Although it had been evaluated before that calcium is the element regulating the synthesis of biomorphs in the presence of $\mathrm{Ca}^{2+}, \mathrm{Ba}^{2+}, \mathrm{Sr}^{2+}$, and nucleic acids, we also wanted to know what would happen in the synthesis of biomorphs in a mixture of different ions containing five alkaline earth elements: $\mathrm{Be}^{2+}, \mathrm{Mg}^{2+}, \mathrm{Ca}^{2+}, \mathrm{Ba}^{2+}$, and $\mathrm{Sr}^{2+}$, in the absence or presence of RNA and gDNA. The first assessed sample was constituted by only $\mathrm{Be}^{2+}, \mathrm{Mg}^{2+}, \mathrm{Ca}^{2+}, \mathrm{Ba}^{2+}$, and $\mathrm{Sr}^{2+}$, at an equimolecular relation. SEM observation of the formed biomorphs revealed a druse morphology (Figure 8a).

\section{$\mathrm{Be}^{2+} / \mathrm{Mg}^{2+} / \mathrm{Ca}^{2+} / \mathrm{Ba}^{2+} / \mathrm{Sr}^{2+}$}

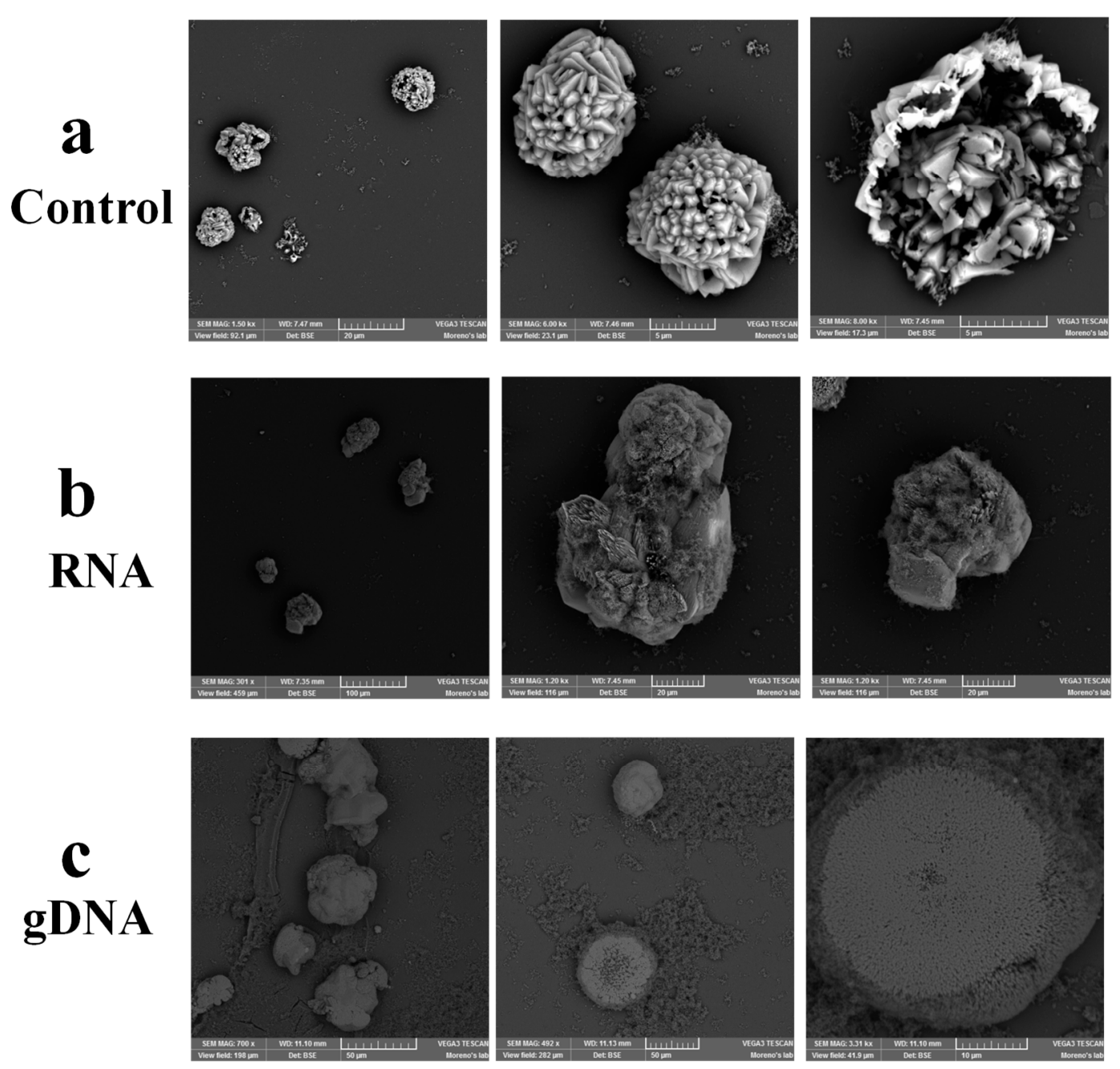

Figure 8. SEM microphotographs of biomorphs obtained with (a) $\mathrm{Be}^{2+} / \mathrm{Mg}^{2+} / \mathrm{Ca}^{2+} / \mathrm{Ba}^{2+} / \mathrm{Sr}^{2+}$, (b) $\mathrm{Be}^{2+} / \mathrm{Mg}^{2+} / \mathrm{Ca}^{2+} / \mathrm{Ba}^{2+} / \mathrm{Sr}^{2+} / \mathrm{RNA}$, and (c) $\mathrm{Be}^{2+} / \mathrm{Mg}^{2+} / \mathrm{Ca}^{2+} / \mathrm{Ba}^{2+} / \mathrm{Sr}^{2+} / \mathrm{gDNA}$.

To determine the chemical composition of the obtained biomorphs, multiple punctual spectra were performed through Raman spectroscopy. Four of the punctual spectra showed peaks at 153-154, 699, and 1070-1074 $\mathrm{cm}^{-1}$ (Figure 9a and Figure S3a), these vibrations correspond to the strontianite $\left(\mathrm{SrCO}_{3}\right)$. 


\section{$\mathrm{Be}^{2+} / \mathrm{Mg}^{2+} / \mathrm{Ca}^{2+} / \mathrm{Ba}^{2+} / \mathrm{Sr}^{2+}$ \\ a Control}

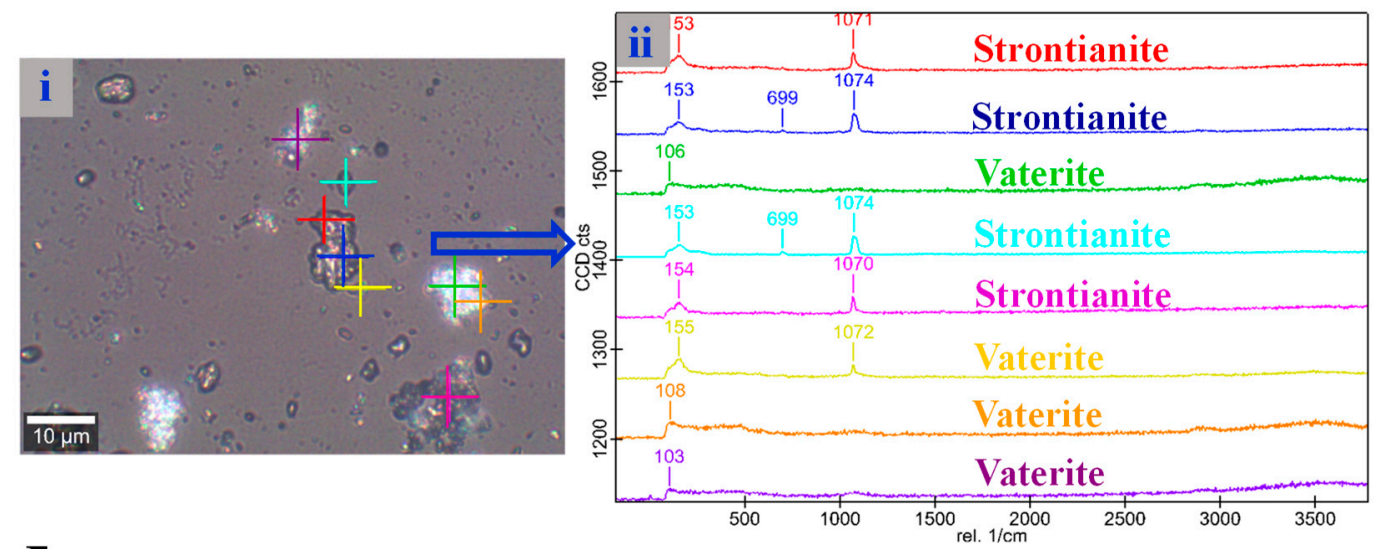

\section{b RNA}
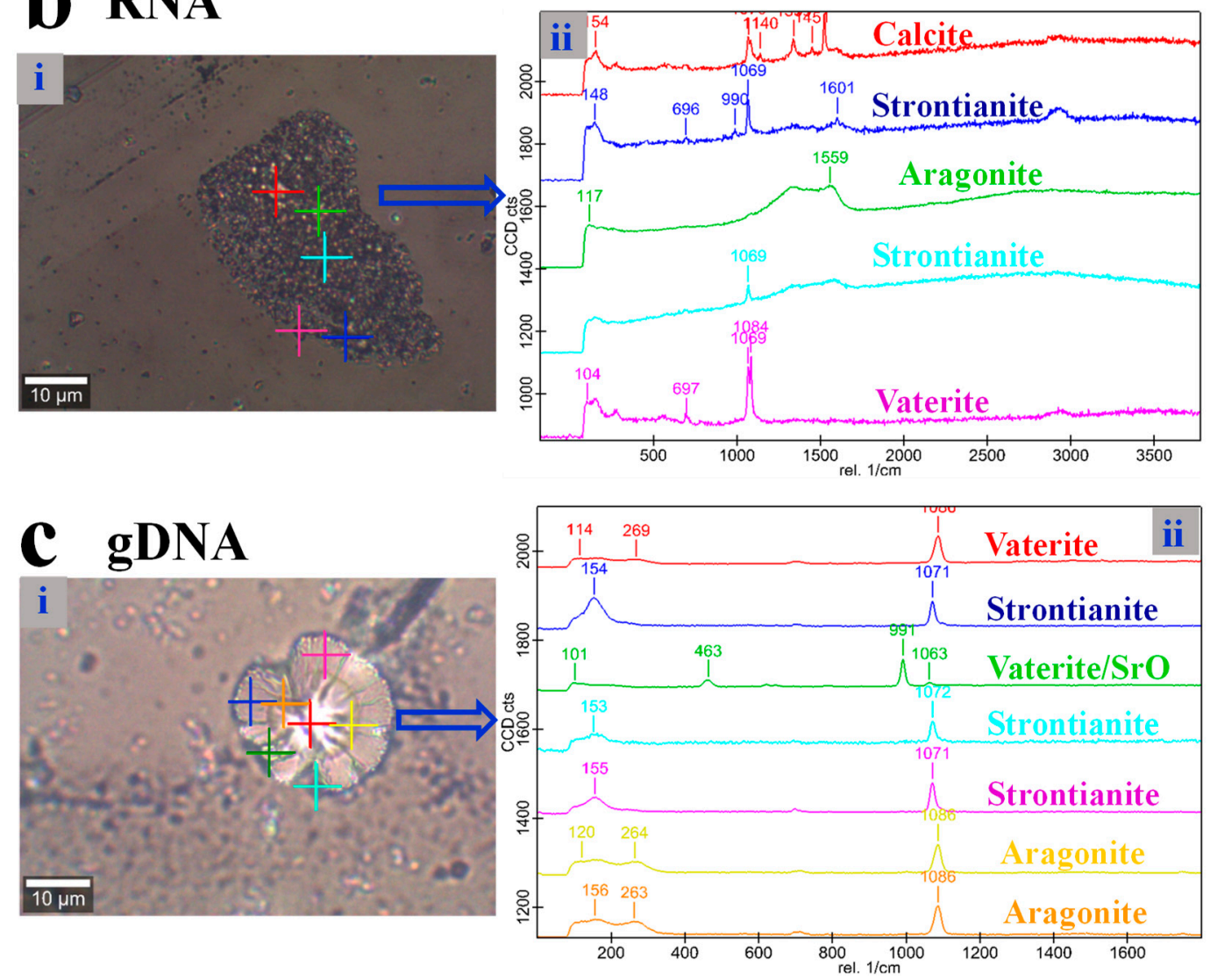

Figure 9. Raman multiple punctual spectra of biomorphs synthesized with (a) $\mathrm{Be}^{2+} / \mathrm{Mg}^{2+} / \mathrm{Ca}^{2+} / \mathrm{Ba}^{2+} / \mathrm{Sr}^{2+}$, (b) $\mathrm{Be}^{2+} / \mathrm{Mg}^{2+} / \mathrm{Ca}^{2+} / \mathrm{Ba}^{2+} / \mathrm{Sr}^{2+} / \mathrm{RNA}$, and (c) $\mathrm{Be}^{2+} / \mathrm{Mg}^{2+} / \mathrm{Ca}^{2+} / \mathrm{Ba}^{2+} / \mathrm{Sr}^{2+} / \mathrm{gDNA}$. (i) Optical image and (ii) multiple spectra.

Whereas the other four punctual spectra presented bands at 103-106, 108, 155, and $1072 \mathrm{~cm}^{-1}$ (Figure 9a) correspond to the polymorph vaterite of $\mathrm{CaCO}_{3}$. These results indicate that, in the presence of five elements, calcium and strontium are the ones that regulate the synthesis of biomorphs. Apparently, the presence of $\mathrm{Be}^{2+}$ and $\mathrm{Mg}^{2+}$ induces an effect so that both $\mathrm{Ca}^{2+}$ and $\mathrm{Sr}^{2+}$ become part of the formed biomorph. When $\mathrm{Ca}^{2+}, \mathrm{Ba}^{2+}$, and $\mathrm{Sr}^{2+}$ are present, strontium is the element that forms part of the biomorph (Figure 7a and Figure S2a). This result could be related to the fact that in nature there are species that contain calcium and strontium [38]. Whereas SEM observations of the metallic 
combinations that included $\mathrm{Be}^{2+}, \mathrm{Mg}^{2+}, \mathrm{Ca}^{2+}, \mathrm{Ba}^{2+}, \mathrm{Sr}^{2+}$, and RNA (Figure 8b) or gDNA (Figure 8c) revealed that no biomorphs were formed, but rather solid structures that mimic bones (Figure 8b), and a flower (Figure 8c). These structures are not hollow; therefore, these structures would not be fulfilling this important characteristic of biomorphs, hence they cannot be considered biomorphs. However, the formed structures became of interest because they were formed in a mixture of different ions containing five chemical elements and nucleic acids. Besides, these solid structures could be considered to be emulating the first structures formed in the Precambrian era, by the existence of the first biomolecule, i.e., RNA. These structures could have been the predecessors of the first cell formed in the Precambrian. Therefore, it was also important to determine the chemical composition of these solid structures through Raman spectroscopy. The multiple punctual spectra of the structure formed with $\mathrm{Be}^{2+}, \mathrm{Mg}^{2+}, \mathrm{Ca}^{2+}, \mathrm{Ba}^{2+}, \mathrm{Sr}^{2+}$, and RNA (Figure 8a) showed that it was composed of calcite, aragonite, and vaterite polymorphs of $\mathrm{CaCO}_{3}$, as well as the strontianite $\left(\mathrm{SrCO}_{3}\right)$ (Figure $9 \mathrm{~b}$ and Figure $\mathrm{S} 3 \mathrm{~b})$. Whereas for the structure formed with $\mathrm{Be}^{2+}, \mathrm{Mg}^{2+}, \mathrm{Ca}^{2+}, \mathrm{Ba}^{2+}, \mathrm{Sr}^{2+}$, and gDNA (Figure 8b), the multiple punctual spectra showed vibrations corresponding to vaterite and aragonite polymorphs of $\mathrm{CaCO}_{3}$ and strontianite, and one punctual spectrum also corresponding to $\mathrm{SrO}$ (Figure 9c and Figure S3c). These results obtained with the different combinations, as shown in Table 2, indicate the availability of several elements to form a new structure in the presence of nucleic acids. Both the RNA and gDNA can interact with the different chemical elements, but possibly those elements with which they form the most stable interactions will be the elements that will specifically form part of organisms; hence, calcium is the most stable element to form the structure followed by strontium, as shown in this work.

Table 2. Prevalent polymorphs obtained in the different assessed combinations.

\begin{tabular}{cll}
\hline Number & Combinations & Prevalent Polymorphs \\
\hline 1 & $\mathrm{Ca}^{2+}+\mathrm{Mg}^{2+}$ & Calcite \\
2 & $\mathrm{Ca}^{2+}+\mathrm{Mg}^{2+}+\mathrm{RNA}$ & Calcite \\
3 & $\mathrm{Ca}^{2+}+\mathrm{Mg}^{2+}+\mathrm{gDNA}$ & Aragonite \\
4 & $\mathrm{Ba}^{2+}+\mathrm{Sr}^{2+}$ & Strontianite \\
5 & $\mathrm{Ba}^{2+}+\mathrm{Sr}^{2+}+\mathrm{RNA}$ & Strontianite \\
6 & $\mathrm{Ba}^{2+}+\mathrm{Sr}^{2+}+\mathrm{gDNA}^{2+}$ & Strontianite \\
7 & $\mathrm{Ca}^{2+}+\mathrm{Ba}^{2+}+\mathrm{Sr}^{2+}$ & Strontianite \\
8 & $\mathrm{Ca}^{2+}+\mathrm{Ba}^{2+}+\mathrm{Sr}^{2+}+\mathrm{RNA}^{2+}$ & Calcite, Vaterite \\
9 & $\mathrm{Ca}^{2+}+\mathrm{Ba}^{2+}+\mathrm{Sr}^{2+}+\mathrm{gDNA}^{2+}$ & Calcite \\
10 & $\mathrm{Be}^{2+}+\mathrm{Mg}^{2+}+\mathrm{Ca}^{2+}+\mathrm{Ba}^{2+}+\mathrm{Sr}^{2+}$ & Strontianite, Vaterite \\
11 & $\mathrm{Be}^{2+}+\mathrm{Mg}^{2+}+\mathrm{Ca}^{2+}+\mathrm{Ba}^{2+}+\mathrm{Sr}^{2+}+\mathrm{RNA}$ & Calcite, Strontianite, Aragonite, Vaterite \\
12 & $\mathrm{Be}^{2+}+\mathrm{Mg}^{2+}+\mathrm{Ca}^{2+}+\mathrm{Ba}^{2+}+\mathrm{Sr}^{2+}+\mathrm{gDNA}$ & Strontianite, Aragonite, Vaterite \\
\hline
\end{tabular}

This information can be correlated with other works that have described that both calcium and strontium are elements identified mainly in 15 algal species, 45 invertebrate species, and six fish species in the Iris sea [38].

\section{Conclusions}

Based on our data, we can infer that the stability presented by calcium, strontium, and certain biomolecules such as nucleic acids could have allowed conserving the first cells and primitive organisms generated in the Precambrian era to our present days and, on the other side, more complex life forms have evolved from relatively simple cells, produced since millions of years ago, such as the higher organisms but conserving calcium and, in some cases, strontium in their structures.

Supplementary Materials: The following are available online at http://www.mdpi.com/2073-4352/9/8/381/s1, Figure S1: Raman spectrum corresponding to the global mapping of biomorphs obtained with the combinations: (a) $\mathrm{Ba}^{2+} / \mathrm{Sr}^{2+}$, (b) $\mathrm{Ba}^{2+} / \mathrm{Sr}^{2+} / \mathrm{RNA}$, and (c) $\mathrm{Ba}^{2+} / \mathrm{Sr}^{2+} / \mathrm{gDNA}$. Figure S2: Raman spectrum corresponding to the global mapping of biomorphs obtained with (a) $\mathrm{Ca}^{2+} / \mathrm{Ba}^{2+} / \mathrm{Sr}^{2+}$, (b) $\mathrm{Ca}^{2+} / \mathrm{Ba}^{2+} / \mathrm{Sr}^{2+} / \mathrm{RNA}$, and (c) $\mathrm{Ca}^{2+} / \mathrm{Ba}^{2+} / \mathrm{Sr}^{2+} / \mathrm{gDNA}$. 
Figure S3: Raman spectrum corresponding to the global mapping of biomorphs obtained with (a) $\mathrm{Be}^{2+} / \mathrm{Mg}^{2+} / \mathrm{Ca}^{2+} / \mathrm{Ba}^{2+} / \mathrm{Sr}^{2+}$, (b) $\mathrm{Be}^{2+} / \mathrm{Mg}^{2+} / \mathrm{Ca}^{2+} / \mathrm{Ba}^{2+} / \mathrm{Sr}^{2+} / \mathrm{RNA}$, and (c) $\mathrm{Be}^{2+} / \mathrm{Mg}^{2+} / \mathrm{Ca}^{2+} / \mathrm{Ba}^{2+} / \mathrm{Sr}^{2+} / \mathrm{gDNA}$.

Author Contributions: Conceptualization, methodology, software, validation, formal analysis, investigation, writing—original draft preparation, and writing—review and editing: M.C.-C. and A.M.

Funding: This research was financed by DGAPA-UNAM project PAPIIT IG200218 (A.M.), and Secretaría de Educación Pública for PRODEP Sabbatical leave support (Oficio No. 511-6/18-5929).

Acknowledgments: Mayra Cuéllar-Cruz acknowledges the sabbatical leave support from SEP-PRODEP (Oficio No. 511-6/18-5929). We would like to thank Dra. Estela Ruiz-Baca for supplying gDNA, pDNA, and RNA. A. Moreno acknowledges to DGAPA-UNAM project PAPIIT IG200218 for the partial support of this project. Authors acknowledge to Dra. Selene Islas for Raman assistance. The authors thank the Laboratorio Universitario de Caracterización Espectroscópica, LUCE-ICAT-UNAM, for the Raman spectroscopic characterization of the samples. The authors acknowledge to Mtra. Ingrid Mascher for the English edition of this contribution.

Conflicts of Interest: The authors declare no conflict of interest.

\section{References}

1. Oparin, A.I. Modern Views on the Origin of Life. Scientia. 1960, 95, 322-326.

2. Cech, T.R.; Grabowski, P.J.; Zaug, A.J. Splicing of the Ribosomal-RNA Precursor and Cyclization of the Excised Intervening Sequence Rna in Nuclei of Tetrahymena. Fed. Proc. 1981, 40, 1651.

3. Cech, T.R. Rna as an Enzyme. Biochem. Int. 1989, 18, 7-14. [CrossRef]

4. Larsen, T.; Sandstrom, B. Effect of Calcium, Copper, and Zinc Levels in a Rapeseed Meal Diet on Mineral and Trace-Element Utilization in the Rat. Biol. Trace. Elem. Res. 1992, 35, 167-184. [CrossRef]

5. Williams, R.J.P.; Fraústo da Silva, J.J.R. Bringing Chemistry to Life: From Matter to Man; Oxford University Press: New York, NY, USA, 1999; pp. 293-298.

6. Fraústo da Silva, J.J.R.; Williams, R.J.P. The Biological Chemistry of the Elements: The Inorganic Chemistry of Life, 2nd ed.; Oxford University Press: New York, NY, USA, 1991; pp. 7-10.

7. Turner, D.R.; Whitfield, M.; Dickson, A.G. The Equilibrium Speciation of Dissolved Components in Fresh-Water and Seawater at 25-Degrees-C and 1 Atm Pressure. Geochim. Cosmochim. Ac 1981, 45, 855-881. [CrossRef]

8. Schopf, J.W. Microfossils of the Early Archean Apex Chert-New Evidence of the Antiquity of Life. Science 1993, 260, 640-646. [CrossRef]

9. Pearce, B.K.D.; Pudritz, R.E.; Semenov, D.A.; Henning, T.K. Origin of the RNA world: The fate of nucleobases in warm little ponds. Proc. Natl. Acad. Sci. USA 2017, 114, 11327-11332. [CrossRef]

10. Zhang, G.; Morales, J.; Garcia-Ruiz, J.M. Growth behaviour of silica/carbonate nanocrystalline composites of calcite and aragonite. J. Mater. Chem. B 2017, 5, 1658-1663. [CrossRef]

11. Garcia-Ruiz, J.M.; Hyde, S.T.; Carnerup, A.M.; Christy, A.G.; Van Kranendonk, M.J.; Welham, N.J. Self-assembled silica-carbonate structures and detection of ancient microfossils. Science 2003, 302, 1194-1197. [CrossRef]

12. Opel, J.; Wimmer, F.P.; Kellermeier, M.; Colfen, H. Functionalisation of silica-carbonate biomorphs. Nanoscale Horiz. 2016, 1, 144-149. [CrossRef]

13. Eiblmeier, J.; Dankesreiter, S.; Ptitzner, A.; Schmalz, G.; Kunz, W.; Kellermeier, M. Crystallization of mixed alkaline-earth carbonates in silica solutions at high pH. Cryst. Growth Des. 2014, 14, 6177-6188. [CrossRef]

14. Cuéllar-Cruz, M.; Islas, S.; González, G.; Moreno, A. The influence of nucleic acids on the synthesis of crystalline $\mathrm{Ca}(\mathrm{II}), \mathrm{Ba}(\mathrm{II})$ and $\mathrm{Sr}(\mathrm{II})$ silica-carbonate biomorphs: Implications to the chemical origin of life on primitive Earth. Cryst. Growth Des. 2019. Available online: https://pubs.acs.org/doi/10.1021/acs.cgd.9b00573. (accessed on 23 July 2019).

15. Nakouzi, E.; Steinbock, O. Self-organization in precipitation reactions far from the equilibrium. Sci. Adv. 2016, 2, e160144. [CrossRef]

16. Garcia-Ruiz, J.M.; Melero-Garcia, E.; Hyde, S.T. Morphogenesis of Self-Assembled Nanocrystalline Materials of Barium Carbonate and Silica. Science 2009, 323, 362-365. [CrossRef]

17. Noorduin, W.L.; Grinthal, A.; Mahadevan, L.; Aizenberg, J. Rationally Designed Complex, Hierarchical Microarchitectures. Science 2013, 340, 832-837. [CrossRef]

18. DeOliveira, D.B.; Laursen, R.A. Control of calcite crystal morphology by a peptide designed to bind to a specific surface. J. Am. Chem. Soc. 1997, 119, 10627-10631. [CrossRef] 
19. Carteret, C.; Dandeu, A.; Moussaoui, S.; Muhr, H.; Humbert, B.; Plasari, E. Polymorphism Studied by Lattice Phonon Raman Spectroscopy and Statistical Mixture Analysis Method. Application to Calcium Carbonate Polymorphs during Batch Crystallization. Cryst. Growth Des. 2009, 9, 807-812. [CrossRef]

20. Vagenas, N.V.; Gatsouli, A.; Kontoyannis, C.G. Quantitative analysis of synthetic calcium carbonate polymorphs using FT-IR spectroscopy. Talanta 2003, 59, 831-836. [CrossRef]

21. Agarwal, P.; Berglund, K.A. In situ monitoring of calcium carbonate polymorphs during batch crystallization in the presence of polymeric additives using Raman spectroscopy. Cryst. Growth Des. 2003, 3, 941-946. [CrossRef]

22. Cuellar-Cruz, M. Synthesis of inorganic and organic crystals mediated by proteins in different biological organisms. A mechanism of biomineralization conserved throughout evolution in all living species. Prog. Cryst. Growth Charact. Mater. 2017, 63, 94-103. [CrossRef]

23. Ruiz-Arellano, R.R.; Moreno, A. Obtainment of Spherical-Shaped Calcite Crystals Induced by Intramineral Proteins Isolated from Eggshells of Ostrich and Emu. Cryst. Growth Des. 2014, 14, 5137-5143. [CrossRef]

24. Ruiz-Arellano, R.R.; Medrano, F.J.; Moreno, A.; Romero, A. Structure of struthiocalcin-1, an intramineral protein from Struthio camelus eggshell, in two crystal forms. Acta Crystallogr. D: Biol. Crystallogr. 2015, 71, 809-818. [CrossRef] [PubMed]

25. Colfen, H. Biomineralization a crystal-clear view. Nat. Mater. 2010, 9, 960-961. [CrossRef] [PubMed]

26. Xiang, L.; Su, J.T.; Zheng, G.L.; Liang, J.; Zhang, G.Y.; Wang, H.Z.; Xie, L.P.; Zhang, R.Q. Patterns of Expression in the Matrix Proteins Responsible for Nucleation and Growth of Aragonite Crystals in Flat Pearls of Pinctada fucata. Plos One 2013, 8, e66564. [CrossRef]

27. Rudel, H.; Muller, J.; Jurling, H.; Bartel-Steinbach, M.; Koschorreck, J. Survey of patterns, levels, and trends of perfluorinated compounds in aquatic organisms and bird eggs from representative German ecosystems. Environ. Sci. Pollut. R 2011, 18, 1457-1470. [CrossRef] [PubMed]

28. Demichelis, R.; Raiteri, P.; Gale, J.D.; Dovesi, R. The Multiple Structures of Vaterite. Cryst. Growth Des. 2013, 13, 2247-2251. [CrossRef]

29. Lowenstam, H.A. Spicular Morphology and Mineralogy in Some Pyuridae (Ascidiacea). B Mar. Sci. 1989, 45, 243-252.

30. Watabe, N. Crystal-Growth of Calcium-Carbonate in Biological-Systems. J. Cryst. Growth 1974, $24,116-122$. [CrossRef]

31. Beniash, E.; Aizenberg, J.; Addadi, L.; Weiner, S. Amorphous calcium carbonate transforms into calcite during sea urchin larval spicule growth. Proc. Roy. Soc. B Biol. Sci. 1997, 264, 461-465. [CrossRef]

32. Lowenstam, H.A.; Abbott, D.P. Vaterite - Mineralization Product of Hard Tissues of a Marine Organism (Ascidiacea). Science 1975, 188, 363-365. [CrossRef]

33. Nehrke, G.; Nouet, J. Confocal Raman microscope mapping as a tool to describe different mineral and organic phases at high spatial resolution within marine biogenic carbonates: Case study on Nerita undata (Gastropoda, Neritopsina). Biogeosci. 2011, 8, 3761-3769. [CrossRef]

34. Soldati, A.L.; Jacob, D.E.; Wehrmeister, U.; Hofmeister, W. Structural characterization and chemical composition of aragonite and vaterite in freshwater cultured pearls. Miner. Mag. 2008, 72, 579-592. [CrossRef]

35. Spann, N.; Harper, E.M.; Aldridge, D.C. The unusual mineral vaterite in shells of the freshwater bivalve Corbicula fluminea from the UK. Naturwissenschaften 2010, 97, 743-751. [CrossRef] [PubMed]

36. Falini, G.; Albeck, S.; Weiner, S.; Addadi, L. Control of aragonite or calcite polymorphism by mollusk shell macromolecules. Science 1996, 271, 67-69. [CrossRef]

37. Veizer, J.; Ala, D.; Azmy, K.; Bruckschen, P.; Buhl, D.; Bruhn, F.; Carden, G.A.F.; Diener, A.; Ebneth, S.; Godderis, Y.; et al. Sr-87/Sr-86, delta C-13 and delta O-18 evolution of Phanerozoic seawater. Chem. Geol. 1999, 161, 59-88. [CrossRef]

38. Templeton, W.L.; Brown, V.M. The Relationship between the Concentrations of Calcium, Strontium and Strontium-90 in Wild Brown Trout, Salmo-Trutta L and the Concentrations of the Stable Elements in Some Waters of the United-Kingdom, and the Implications in Radiological Health Studies. Air Water Pollut. 1964, 8, 49-75.

39. Rouillard, J.; García-Ruiz, J.M.; Gong, J.; van Zuilen, M.A. A morphogram for silica-witherite biomorphs and its application to microfossil identification in the early earth rock record. Geobiology 2018, 16, 279-296. [CrossRef] 
40. Bonales, L.J.; Munoz-Iglesias, V.; Santamaria-Perez, D.; Caceres, M.; Fernandez-Remolar, D.; Prieto-Ballesteros, O. Quantitative Raman spectroscopy as a tool to study the kinetics and formation mechanism of carbonates. Spectrochim. Acta A 2013, 116, 26-30. [CrossRef]

41. Rieder, K.H.; Migoni, R.; Renker, B. Lattice-Dynamics of Strontium Oxide. Phys. Rev. B 1975, 12, 3374-3379. [CrossRef]

42. Lin, C.C.; Liu, L.G. High-pressure Raman spectroscopic study of post-aragonite phase transition in witherite $\left(\mathrm{BaCO}_{3}\right)$. Eur. J. Miner. 1997, 9, 785-792. [CrossRef]

43. Bowen, H.J.M. Strontium and Barium in Sea Water and Marine Organisms. J. Mar. Biol. Assoc. U.K. 1956, 35, 451-460. [CrossRef]

44. Niedermeier, M.; Gierlinger, N.; Lutz-Meindl, U. Biomineralization of strontium and barium contributes to detoxification in the freshwater alga Micrasterias. J. Plant. Physiol. 2018, 230, 80-91. [CrossRef] [PubMed]

45. Isermann, K.; Glatzle, A. Discrimination of Calcium against Strontium in Plants with a Cryptating Agent. Naturwissenschaften 1975, 62, 238-239. [CrossRef]

46. Gilbert, W. Origin of Life: The RNA World. Nature 1986, 319, 618. [CrossRef]

47. Christy, A.G. A review of the structures of vaterite: The Impossible, the possible and the likely. Cryst. Growth Des. 2017, 17, 3567-3578. [CrossRef]

48. Currey, J.; Taylor, J. The mechanical behaviour of some molluscan hard tissues. J. Zool. 1974, 173, 395-406. [CrossRef]

49. Burgess, K.M.N.; Bryce, D.L. On the crystal structure of the vaterite polymorph of $\mathrm{CaCO}_{3}$ : A calcium-43 solid-state NMR and computational assessment. Solid State Nucl. Mag. Res. 2015, 65, 75-83. [CrossRef] [PubMed]

50. Mann, K. The calcified eggshell matrix proteome of a songbird, the zebra finch (Taeniopygia guttata). Proteome. Sci. 2015, 13, 29. [CrossRef] [PubMed]

51. Reyes-Grajeda, J.P.; Moreno, A.; Romero, A. Crystal structure of ovocleidin-17, a major protein of the calcified Gallus gallus eggshell - Implications in the calcite mineral growth pattern. J. Biol. Chem. 2004, 279, 40876-40881. [CrossRef] [PubMed]

52. Vanhoutte, P.M.; Collis, M.G.; Janssens, W.J.; Verbeuren, T.J. Calcium Dependence of Prejunctional Inhibitory Effects of Adenosine and Acetylcholine on Adrenergic Neurotransmission in Canine Saphenous Veins. Eur. J. Pharmacol. 1981, 72, 189-198. [CrossRef]

53. Douglas, W.W.; Rubin, R.P. The Role of Calcium in Secretory Response of the Adrenal Medulla to Acetylcholine. J. Physiol. 1961, 159, 40-57. [CrossRef] [PubMed]

54. Katz, B. Neural transmitter release: From quantal secretion to exocytosis and beyond. J. Neurocytol. 1996, 25, 677-686. [CrossRef] [PubMed]

55. White, P.J.; Broadley, M.R. Calcium in plants. Ann. Bot. 2003, 92, 487-511. [CrossRef] [PubMed]

56. Dominguez, D.C. Calcium signalling in bacteria. Mol. Microbiol. 2004, 54, 291-297. [CrossRef] [PubMed] 